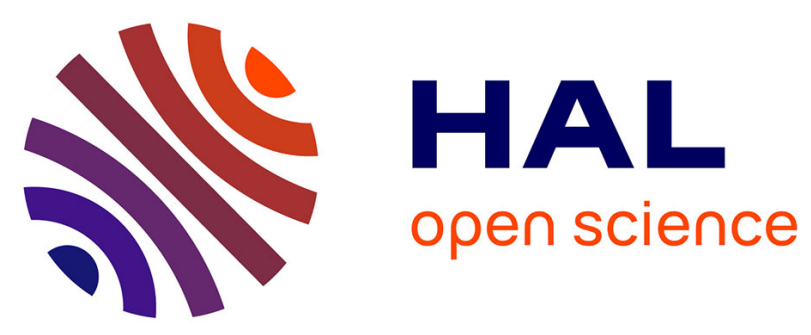

\title{
Small-scale lobate hillslope features on Mars: A comparative 3D morphological study with terrestrial solifluction lobes and zebra stripe lobes \\ Renaldo Gastineau, Susan Conway, Andreas Johnsson, Jana Eichel, Nicolas Mangold, Peter M Grindrod, Tatiana Izquierdo
}

\section{To cite this version:}

Renaldo Gastineau, Susan Conway, Andreas Johnsson, Jana Eichel, Nicolas Mangold, et al.. Smallscale lobate hillslope features on Mars: A comparative 3D morphological study with terrestrial solifluction lobes and zebra stripe lobes. Icarus, 2020, 342, pp.113606. 10.1016/j.icarus.2019.113606 . hal-02499008

\section{HAL Id: hal-02499008 https://hal.science/hal-02499008}

Submitted on 21 May 2020

HAL is a multi-disciplinary open access archive for the deposit and dissemination of scientific research documents, whether they are published or not. The documents may come from teaching and research institutions in France or abroad, or from public or private research centers.
L'archive ouverte pluridisciplinaire HAL, est destinée au dépôt et à la diffusion de documents scientifiques de niveau recherche, publiés ou non, émanant des établissements d'enseignement et de recherche français ou étrangers, des laboratoires publics ou privés. 
1 Small-scale lobate hillslope features on Mars: A comparative 3D morphological study with

2 terrestrial solifluction lobes and zebra stripe lobes

3

4 Renaldo Gastineau ${ }^{1,2 *}$

5 Susan J. Conway ${ }^{1}$

6 Andreas Johnsson ${ }^{3}$

$7 \quad$ Jana Eichel ${ }^{4}$

$8 \quad$ Nicolas Mangold ${ }^{1}$

9 Peter M. Grindrod ${ }^{5}$

10 Tatiana Izquierdo ${ }^{6}$

13 1. CNRS UMR 6112 Laboratoire de Planétologie et Géodynamique, Nantes, France.

14 2. Univ. Grenoble Alpes, Univ. Savoie Mont Blanc, CNRS, IRD, IFSTTAR, ISTerre, 38000 15 Grenoble, France.

16 3. Department of Earth Sciences, University of Gothenburg, Gothenburg, Sweden.

17 4. Karlsruhe Institute of Technology (KIT), Institute of Geography und Geoecology, Kaiserstr. 12, 1876131 Karlsruhe Germany.

19 5. Department of Earth Sciences, The Natural History Museum, London, UK.

20 6. Instituto de Investigaciones Científicas y Tecnológicas de la Universidad de Atacama (IDICTEC21 UDA). Avenida Copayapu, 485, Copiapó, Chile.

22

$23 *$ corresponding author: renaldo.gastineau@univ-grenoble-alpes.fr 
1. Small scale lobes (SSL) on Mars share more morphometric characteristics with terrestrial solifluction lobes than zebra stripe lobes from seismic shaking in the Atacama Desert.

2. Martian SSL only occur on slopes greater than $\sim 10^{\circ}$, a constraint not observed for lobes on Earth and could be due to differences in material properties or thermal regime.

3. Martian SSL differ from terrestrial ones in two other ways: they can have larger dimensions and they tend to occur near the top of the slope as opposed to the bottom. 
Small-scale lobes (SSL) observed at the surface of Mars are thought to be the result of solifluction. Hence, their existence has important implications for our understanding of recent climate history, the distribution of thaw liquids and its geomorphic effects, as water is believed not to have been recently stable at the martian surface. These small-scale lobes are limited to sloping terrains and often occur alongside polygonal patterned ground attesting to the presence of ice in the environment. In this study, we perform a comparative 3D morphometric analysis of the lobes on Mars with terrestrial analogues. We use data from High Resolution Imaging Science Experiment (HiRISE) camera in order to create Digital Terrain Models (DTMs) on Mars at $1 \mathrm{~m} /$ pix. For the terrestrial analogues, we use DTMs and orthophotos from five periglacial environments with solifluction lobes and from one site with lobate features found in the Atacama Desert. The lobate features in the Atacama are found within features called "zebra stripes", which are apparently unique to the Atacama and are now generally accepted to be the result of seismic shaking. We show that SSL on Mars overlap morphometrically with terrestrial solifluction lobes, and are less similar to zebra stripe lobes. The majority of martian SSL occur below the angle of repose which demonstrates that a dry fall mechanism cannot be responsible for their formation and that lubrication of the subsurface is required. We found that martian SSL only occur on slopes greater than $\sim 10^{\circ}$, a constraint not observed for terrestrial solifluction lobes nor zebra stripe lobes in Atacama. We hypothesise that this apparent constraint does not result from the lowered gravity on Mars, but instead from differing soil properties and/or thermal regime between Mars and Earth which affects the slope at which creep can initiate. We cannot rule out a role of $\mathrm{CO}_{2}$ sublimation in lobe-formation based on our terrestrial measurements.

Keywords: Mars; Surface activity; Periglacial processes; Terrestrial analogues; 3D analysis

\section{Introduction}

Solifluction landforms, in the form of downslope oriented lobes, are common in cold-climate environments on Earth. Mars is currently a cold hyper-arid desert planet where contemporary liquid water may be extremely localized and rare (e.g., Ojha et al., 2015). Lobate hillslope features, similar in morphology to terrestrial solifluction lobes have been observed on Mars (Mangold, 2005; Gallagher et al., 2011; Hauber et al., 2011; Johnsson et al., 2012; Balme et al., 2013; Johnsson et al., 2018). These landforms, termed "Small-Scale Lobes" (SSL), are interpreted to have been formed by solifluction processes due to their morphological similarity to solifluction lobes on Earth (Fig. 1; Gallagher et al., 2011; Johnsson et al., 2012).

We identified a new terrestrial environment where lobate forms are observed on sloping terrain and could therefore provide an alternative mechanism to solifluction as an explanation for martian SSL. In the Atacama Desert, lobate forms visible in aerial images on small hills, have been attributed to the action of salts (Beaty, 1983), overland flow (Owen et al., 2013), and seismic shaking (May et al., 2019). This desert is the driest on Earth, which is one of the closest analogues for the current martian climate. One of the main problems facing the solifluction interpretation of SSL on Mars is the fact that extensive thaw is not thought to have been possible in the last $1 \mathrm{Ga}$ (e.g., Kreslavsky et al., 2008). Hence, if a landform similar to SSL can be found in a dry terrestrial environment, it could provide a possible solution to this problem. The lobes are found within zebra stripes in Atacama, whose origin is not fully understood, but is now generally accepted to be the result of seismic shaking (May et al., 2019). As seismic shaking from impacts or marsquakes is becoming recognised as a potential element in martian landscape evolution (Roberts et al., 2012; Brown and Roberts, 2019; Kumar et al., 2019), this forms a potentially interesting alternative formation mechanism for martian SSL. 
In this study, we performed a comparative morphometric analysis of SSL on Mars, terrestrial periglacial solifluction lobes and the Atacama lobate forms. Previous works relied on plan-view measurements and observations of martian SSL such as the study of the distribution of small-scale lobes using HiRISE images, or their relationship to other possible ground ice-related landforms such as gullies, polygonally patterned ground, and stripes (Gallagher et al., 2011; Johnsson et al., 2012; Nyström and Johnsson, 2014; Johnsson et al., 2018). Here, we add topographic context and quantitative 3D analysis of these landforms. These are the first large systematic 3D measurements of these features. For this we used data from HiRISE to create DTMs (Digital Terrain Models). For the terrestrial analogues, we used DTMs and orthophotos from Svalbard (Adventdalen), Greenland (Carlsberg Fjord), Sweden (Hödj), the French Alps (Termignon), Iceland (Tindastóll), and the Atacama Desert (Antofagasta). The aim of the study is to use both the new topographic information and comparison with an alternate terrestrial lobate form to assess whether the solifluction interpretation for the martian SSL should be maintained. If the small-scale lobes observed on Mars are indeed the result of solifluction, their existence has important implications for our understanding of recent climate history, the distribution of thaw liquids near the surface, its geomorphic effects and implications for Special Regions for planetary protection (Rummel et al., 2014).

\subsection{Small-scale lobes on Mars}

Mars has abundant ground ice from the mid- to high latitudes as shown by GRS (Gamma Ray Spectrometer on Mars Odyssey) (Boynton et al., 2002; Pathare et al., 2018), radar (Mouginot et al., 2010; Bramson et al., 2015; Stuurman et al., 2016) and imaging datasets of fresh craters exposing ice (Byrne et al., 2009; Dundas et al., 2014). In particular the ubiquitous presence of polygonally patterned ground at latitudes higher than $\sim 55^{\circ}$ and discontinuously between $30^{\circ}$ and $55^{\circ}$ is thought to represent the thermal contraction of these ground ice deposits (Mangold et al., 2004; Levy et al., 2009). $98 \%$ of martian SSL are found adjacent to, and sometimes superposed on, polygonally patterned ground (Nyström and Johnsson, 2014). If martian SSL are formed by solifluction then they could indicate thaw of this ground ice in the recent past. In support of this hypothesis is the rare observation of ploughing boulders associated with martian SSL (Fig. 2; Johnsson et al., 2018), which on Earth, are intimately associated with solifluction (French, 1976; Ballantyne and Harris, 1994; Ballantyne, 2001). The latitude dependence of SSL orientation also suggests a climatic driver in their formation. SSL are limited to sloping terrain and mainly observed in the northern hemisphere (e.g., Johnsson et al., 2018; Barrett et al., 2018). The southern hemisphere has more steep slopes (Kreslavsky and Head, 2003), so the relative paucity of SSL is not clearly understood, but could be linked to hemispherical differences in surface properties (Johnsson et al., 2018). Mid-latitude $\left(55^{\circ}\right.$ to $\left.65^{\circ}\right) \mathrm{SSL}$ have a pole-facing preference whereas high-latitude $\left(65^{\circ}\right.$ to $\left.80^{\circ}\right)$ ones tend to have an equator-facing preference (Nyström and Johnsson, 2014).

In the arid climate of present-day Mars, the production of liquid water is still a point of debate, and is considered to be slightly more probable in the recent past (e.g., Richardson and Mischna, 2005). This is because Mars has undergone recent climatic shifts due to the variations in its orbital parameters. Contrary to the Earth which is stabilized by the Moon, the obliquity of Mars, currently equal to $25.2^{\circ}$, changes by approximately $20^{\circ}$ on a $100 \mathrm{ka}$ cycle (Laskar et al., 2004). According to modelling by Kreslavsky et al., (2008), conditions favouring the formation of an active layer (a thawed layer atop the permafrost) could have last been reached between 10 and $5 \mathrm{Ma}$.

SSL have been studied by several authors using HiRISE images (Gallagher et al., 2011; Johnsson et al., 2012; Nyström and Johnsson, 2014; Johnsson et al., 2018). As reported by Nyström and Johnsson, (2014), 48\% of martian SSL occur in craters that also host gullies. SSL superpose gullies (Gallagher and Balme, 2011) suggesting their age to be equivalent to those of gullies (i.e. the last few Ma; Reiss 
et al., 2004; Schon et al., 2009; De Haas et al., 2015). Whether gullies are caused by flowing liquid water/brine or $\mathrm{CO}_{2}$ sublimation triggered flows is a current point of debate (e.g., Conway et al., 2018). Their intimate association with martian SSL suggests that the two landforms are likely to be linked as a landform assemblage, i.e. formed by related processes (Gallagher et al., 2011). Liquid water could be favoured by the presence of perchlorates in the regolith, which were found at the Phoenix site. Perchlorates are molecules which have a eutectic point at $240 \mathrm{~K}$, that maintain water in a liquid state at temperatures below its freezing point (Pestova et al., 2005; Marion et al., 2010). Sublimation of $\mathrm{CO}_{2}$ frost (Sylvest et al., 2016) is not currently favoured to explain martian SSL, because lobes at the foot of the slope are hard to explain as they are lower than the dynamic angle of friction which limits mass wasting processes (Johnsson et al., 2012, 2018). However, the distribution of seasonal $\mathrm{CO}_{2}$ matches with the observed latitudinal distribution of martian SSL and a recent study has revealed active rock motion associated with SSL and the seasonal $\mathrm{CO}_{2}$ ice deposits (Dundas et al., 2019).

Finally martian SSL are often associated with landforms that resemble terrestrial sorted patterned ground (Johnsson et al., 2012, 2018), which are found in environments with active freeze-thaw cycling. The patterns are outlined by increased concentrations of clasts and can take the form of piles, nets, polygons, circles or stripes depending on the clast concentration and surface slope (Kessler and Werner, 2003). Such patterns have been reported on Mars (Soare et al., 2016; Barrett et al., 2017) and are found in proximity to SSL (Gallagher et al., 2011; Johnsson et al., 2018).

\subsection{An overview of lobe-producing processes on Earth}

Mass wasting is defined as the downslope movement of soil/rock induced by gravity. Mass wasting encompasses a number of processes, which can operate together or separately (e.g., Selby, 1982) (Fig. 3a). However, not many of these processes produce lobes. Solifluction processes are known to produce lobes whereas soil creep on its own does not, as shown by field observations (Fig. 3a). Commonly, soil creep is described as the process of downslope soil movement driven by a range of processes (Heimsath and Jungers, 2013) such as moisture and/or temperature fluctuations, dissolution and recrystallization of salts (Pawlik and Samonil, 2018). Solifluction, on the other hand, refers to slow downslope movement of water-saturated debris or soils (Gallagher et al., 2011) by cyclic freezing and thawing of water (e.g., Matsuoka, 2001).

Solifluction can be divided into four processes (Matsuoka, 2001). 1) Frost creep is a ratchet-like downslope movement due to a normal frost heave followed by thaw and near vertical settling (Fig. $3 b)$. Frost creep is divided into diurnal and annual frost creep depending on the timescale over which the soil has undergone the freeze-thaw cycle. The timescale of the freezing affects the depth of the movement, for example diurnal frost creep mainly affects the first centimetres of the soil (Matsuoka, 1998) whereas annual frost creep affects a few decimetres (Smith, 1988). 2) Needle ice creep is special kind of diurnal frost creep, occurring when superficial surface debris is lifted perpendicular to the surface by ice needles and then falls again vertically on thawing (Li et al., 2018). 3) Gelifluction occurs on thaw when self-compaction leads to high pore-water pressures resulting in plastic deformation of the soil (Fig. 3b; Harris et al., 2008). 4) When conditions of two-sided freezing occur, there is an additional process called "plug-like" flow in cold permafrost conditions. In this case, the whole active layer is set in motion (Matsuoka, 2001). Morphologically, solifluction lobes can be divided into stone- and turf-banked lobes. However, this morphometric classification does not imply a difference in process forming the lobe. It is likely that vegetation (and animals) strongly influence creep processes and thereby also landform development and morphometry (Eichel et al., 2017). Turf- 
banked lobes have, for example, a higher sediment thickness and a lower surface velocity than vegetation-free lobes (stone-banked lobes) (Matsuoka, 2001; Harris et al., 2008).

Debris flows are another lobe producing process (Draebing and Eichel, 2018). Debris flows are rapid mass movements of mixtures of sediment (40-50\%) and water moving under gravity (Iverson, 1997) and deposit lateral levees as well as terminal lobes of unsorted materials. Draebing and Eichel, (2018) compared former debris flow lobes reworked by solifluction with solifluction lobes and only found slight geomorphic differences, with reworked debris flow lobes possessing a more half-moon-like shape while solifluction lobes were more tongue-shaped. However, lobes developed from debris flow lobes have steep catchment areas and a debris flow origin can be deduced from their context (e.g. foot of proximal moraines or alluvial fan; De Haas et al., 2015; Draebing and Eichel, 2018). We do not examine this particular lobe-forming process in any further detail as we consider similar environmental conditions are required as those that form solifluction lobes sensu stricto.

\section{Study sites}

\subsection{On Mars}

We studied sites containing two types of martian SSL, sorted lobes or clast-banked lobes which have a distinct clast-rich front, and non-sorted lobes where the lobate shape is visible because of the relief (Gallagher et al., 2011; Johnsson et al., 2012). They are thought to be analogous to stone-banked and turf-banked lobes on Earth based on their shape, respectively (Fig. 4; Benedict, 1976). Based on the dataset presented in Johnsson et al. $(2012,2018)$ and the location of HiRISE images, 36 stereo pairs hosting SSL were identified from which DTMs could be made (see Table 1 and Fig. 5 for their locations). Seven stereo pairs were processed into DTMs in the northern hemisphere and one in the southern hemisphere. All of the sites are located on crater walls where sloping terrains are present. The craters range from 1.8 to $16.6 \mathrm{~km}$ in diameter, and they are all simple bowl-shaped craters. Seven of the craters also contain gullies and six of the craters also have polygonally patterned ground (Table 2). Only the crater at site L_63_292 contains any appreciable infill in the form of dark-toned aeolian dunes. The relatively young age of these craters is attested by their easily identifiable ejecta blankets, which have few superposed impact craters.

\subsection{On Earth: solifluction lobes}

Five terrestrial analogues with solifluction lobes have been included in this study: Svalbard (Adventdalen), Greenland (Carlsberg Fjord), Sweden (Hödj), the French Alps (Termignon) and Iceland (Tindastóll) (Fig. 6 and Table 3). These sites are all in periglacial environments, which are defined as an environment where the phenomena of freezing and thawing and associated permafrost related processes occur (French, 1976; Slaymaker, 2011). In this study, we include sites where solifluction lobes are found in the northern hemisphere, and each site has a different climatic context, soil properties, vegetation type and geology (Table 3). Thus, our terrestrial analogues represent a varied sample of the possible types of solifluction lobes found on Earth.

\subsection{On Earth: zebra stripe lobes in the Atacama Desert}

In the Atacama Desert, lobate-shaped in plan-view are observed despite it being one of the driest places on Earth (Clarke, 2006; Owen et al., 2013). It is unlikely, however, that they are formed by solifluction, so provide an alternate Earth analogue for comparison to martian SSL. The Atacama Desert extends from southern Peru to northern Chile with rainfall of $\sim 2 \mathrm{~mm} /$ year, making this desert the driest on Earth (Clarke, 2006). Thus, it is often used as an analogue for the current climate of 
Mars (Catling et al., 2010). Lobate features have been reported on hillslopes in the Atacama and similar lobes have not been reported from any other desert on Earth to our knowledge. They are found within "zebra stripes", so called because of the contrast between the darkly-varnished gravels and the light-coloured, salt-rich soil (Fig. 7). Initially, these features were attributed to salt heave (Beaty, 1983), later reinterpreted to be due to ancient overland flow events (Owen et al., 2013) and most recently attributed to seismic shaking (May et al., 2019).

Beaty, (1983) was the first author to mention zebra stripes in the literature, calling them "tiger stripes". He proposed that they are formed due to the shrinking and swelling of the ubiquitous salts in the soil. This process occurs when the soil undergoes repeated cycles of thermal and/or desiccation induced contraction and expansion of salt minerals (Buck et al., 2006). Over a long period $\left(\sim 10^{6}\right.$ years) these processes could form salt wedges and patterned ground (Buck et al., 2006) somewhat equivalent to ice lenses and ice wedge polygons formed in periglacial terrains on Earth. Owen at al. (2013) further studied zebra stripes and concluded that rare pluvial events causing overland flow could explain the grain-sorting observed within the zebra stripes on hillslopes in the Atacama.

A new study has re-examined the formation of this landform (May et al., 2019). They showed, based on UAV-derived photos that the frontal part of zebra stripes have a distinct boundary, which is almost contour-parallel yet consists of multiple bulges which look like downslope-facing lobes. They found a remarkable similarity in shape between the lobes developed in zebra stripes and deposits developed in experiments examining the process of segregation-induced granular fingering. They propose a combination of seismic shaking (Matmon et al., 2015) and instantaneous dry granular free surface flows as the key mechanism for zebra stripe formation. They also found that the lobes developed in zebra stripes in their study area have width and length ranging from 1 to $3 \mathrm{~m}$, and 10 to $30 \mathrm{~m}$ respectively, and that they form on slopes ranging from 10 to $20^{\circ}$.

\section{Approach}

Images from the HiRISE camera on the Mars Reconnaissance Orbiter (MRO) with a $\sim 25 \mathrm{~cm} /$ pixel resolution were used to derive Digital Terrain Models using the Integrated Software for Imagers and Spectrometers (ISIS3) and Socet Set 5.6.0 following the method outlined in Kirk et al., (2008). Five DTMs with nominal spatial resolution and relative vertical accuracy of $1 \mathrm{~m}$ and $\sim 0.5 \mathrm{~m}$ respectively were created. Three further publically available DTMs derived using the same procedure were downloaded from https://www.uahirise.org/dtm/. Moreover, six terrestrial analogues have been included in this study: Svalbard, Iceland, Sweden, Greenland, the French Alps and the Atacama Desert, whose digital elevation models were derived from photogrammetry or laser altimetry with spatial and vertical resolutions equivalent to or better than the martian data. Locations and detailed information is given in Fig. 6, Table 3 and in the sections below.

\subsection{Elevation data processing and lobe measurements}

For martian DTMs we used sinusoidal projections centred on the longitude of the lobe locations. For the terrestrial DTMs, we used local Universal Transverse Mercator (UTM) projections. The narrow extent $\left(6^{\circ}\right.$ of longitude and $8^{\circ}$ of latitude wide) of each zone of this projection system ensures minimal scale distortion within each zone. For the DTM in the French Alps we used the official French map projection system: Lambert-93 (EPSG 2154), a conic and conformal projection. Thus, our projections minimise spatial distortion which are negligible compared to the other potential sources of error in our study. 
To smooth out metre-scale noise in the stereo-derived martian DTMs we passed a mean moving window filter over the DTM of 3 pixels and 5 pixels, each twice. We applied the same procedure to the terrestrial data for consistency. Measurement of lobe geometries was made using orthophotos and hillshaded relief rendering of the topography in ArcGIS 10.4 (Fig. 8). We report these measurements as 3D rather than 2D distances to make full use DTMs. The width of each lobe is measured at the furthest upslope extent of lobes while their length is measured perpendicular to the latter and represents the maximum downslope distance between the upslope end and the riser (the toe). Because downslope movement should follow the line of maximum gradient, we used contour lines to help guide these measurements. The slope for each lobe was calculated along the downslope-axis by averaging the slope map values that fell under the line. All of the data were then extracted and plotted with Matlab. To better define the nearest upslope ridge and quickly identify the steepest upslope direction, we calculated the compound topographic index for each DTM, which does not imply that the study area is wet. It produces a visualisation of the orientation of the steepest downslope/upslope direction that also highlights local ridges (Fig. 8). On Mars, the nearest upslope ridge is more readily identifiable because it is usually the crater rim. The normalised distance of each lobe from its uppermost point to its nearest associated ridge indicates the distribution of lobes along the slopes (Fig. 9a). The length of the slopes varied on each studied site, it is necessary to normalize the distance of each lobe with the total length of the hillslope in order to make meaningful comparisons. We also used topographic long profiles in order to study the position of the lobes upon the hillslope and to visualise the curvature of profiles where they occur.

We estimated the maximum uncertainty in our digitisation of the width and length of the lobes (and of the ridges) to be on the order of 1-2 pixels in the orthoimages, as the lobes were easily distinguishable from their background. This uncertainty translates to at worst 1 metre for the coarsest terrestrial orthophoto resolution (Sweden: $1 \mathrm{~m} /$ pix) and about $15 \mathrm{~cm}$ for the finest one (Iceland: 0.15 $\mathrm{cm} /$ pixel). For the martian orthophotos, this corresponds to $25 \mathrm{~cm}$. Such uncertainties have a negligible impact on our length and width measurements which are typically on the order of tens if not hundreds of metres.

The relative vertical precision of the martian DTMs used in this study is better than $\sim 0.4 \mathrm{~m}$ (Table 1). For the terrestrial DTMs, LIDAR (LIght Detection And Ranging) data typically have a maximum vertical precision of $\sim 0.2 \mathrm{~m}$ (Hodgson and Bresnahan, 2004) while the Atacama DTM made by stereophotogrammetry and based on previous experience should have a vertical precision of $\sim 0.5 \mathrm{~m}$ (Conway et al., 2015). Such uncertainties can lead to significant errors of slope measurements at the pixel-scale, but over length-scales of tens to hundreds of metres become negligible.

\section{Results}

\subsection{Morphometric properties of lobes}

We analysed 5148 lobes in total, with 1901 SSL on Mars and 3247 lobes on Earth, of which 2759 are solifluction lobes and 488 are zebra stripe lobes (Table 4). On Mars, we find SSL on slopes ranging from $\sim 10^{\circ}$ to $\sim 38^{\circ}$, with a mean and median value of $25^{\circ}$ despite all our DTMs containing areas where slopes were below $10^{\circ}$. On Earth, solifluction lobes are found on slopes between $\sim 0^{\circ}$ and $\sim 35^{\circ}$, the mean and median values are both equal to $16^{\circ}$. For zebra stripe lobes, the slope where they occur ranges between $\sim 5$ and $\sim 30^{\circ}$, the mean and median values are 18.5 and $17^{\circ}$, respectively (Fig. 10). Martian SSL tend to be longer and wider than terrestrial solifluction lobes which in turn tend to be longer and wider than zebra stripe lobes (Fig. 11). Martian SSL overlap with the range of dimensions 
expressed by solifluction lobes on Earth, whereas the zebra stripe lobes of the Atacama Desert differ from both as they do not exceed $20 \mathrm{~m}$-wide and $20 \mathrm{~m}$-long.

Fig. 11 shows that, for all three lobe types, lobe length tends to increase with lobe width and for terrestrial solifluction lobes this trend has a gradient slightly lower than the 1:1 line, which was also found for solifluction lobes in Austria (Matsuoka et al., 2005). Martian SSL follow a similar trend to terrestrial solifluction lobes, but can also increase in length faster than they increase in width.

The width to length ratio of martian SSL increases slightly with decreasing slope (Fig. 9b) and the same trend is identifiable for zebra stripe lobes. On Earth, the W:L of solifluction lobes has a maximum value of $\sim 15$ for almost flat surfaces. On Mars there is a slight tendency for the length to decrease with increasing slope (Fig. 9c), but this trend is not apparent for the terrestrial analogues. On Earth we note that there is a maximum length of approximately $150 \mathrm{~m}$ for solifluction lobes and $\sim 20 \mathrm{~m}$ for zebra stripe lobes. Lobes are clearly longer on Mars in particular when the slope decreases towards $20^{\circ}$, where the SSL reach a maximum length of $\sim 700 \mathrm{~m}$.

\subsection{Topographic context of lobes}

Fig. 12 shows slope profiles illustrating the typical positions of the lobate features studied within the surrounding topographic context. Lobes can span the whole topographic profile or be constrained to a small part of it. All slope profiles are concave except for the ones in the Atacama Desert. For site L_-45_9, SSL are located mid-slope, whereas in site L_63_292, SSL are located close to the crater rim and at site L_59_44, SSL are spread along the whole profile. In Sweden, solifluction lobes are spread along the whole profile apart from at the highest slopes close to the ridge. On Svalbard, all of the profile has lobes, even the near-flat surface at the bottom of the profile. In contrast to all other sites, the profiles in the Atacama Desert are convex and shorter. Here, zebra stripes are constrained to the upper and middle part of slopes, which are relatively short (note the differences in scale). These case-study examples are reflected by our observations of the whole population. In Fig. 9a, the normalised distance from each lobe to the nearest ridge is plotted against their width to length ratio. On Mars, SSL occur mostly near to the ridge. Only a few SSL are found downslope, where the slopes are less steep contrary to solifluction lobes on Earth, which are mostly found in the lower part of the slopes. Very few solifluction lobes are found near the ridge of hillslopes. The zebra stripe lobes, however, occur across all values.

\section{Discussion}

\subsection{Martian SSL and terrestrial solifluction lobes}

Previous work has concluded that SSL on Mars are likely to be a result of solifluction, because they have similar plan-view morphology, slope-side setting and associated landforms (e.g. ploughing boulders) as solifluction lobes on Earth (Johnsson et al., 2018). Our data reinforce the similarity found in previous work, as we find that martian SSL have similar dimensions, similar topographic position and are found on similar slopes as solifluction lobes. In addition, the fact that SSL on Mars tend to have a lower W:L ratio at higher slope gradients indicates their formation mechanics may be fundamentally similar to solifluction lobes (Fig. 9b), which are predicted by theory to be longer on higher slope gradients (Ballantyne and Harris, 1994).

We find that martian lobes differ from terrestrial ones in three ways: they can have larger dimensions, they tend to occur near the top of the slope as opposed to the bottom and martian SSL are rarely found at slopes $<15^{\circ}$ (Fig. 10). The slope difference is discussed further in the section that follows. The 
origin of martian SSL near the top of the slope suggests a weak influence of upslope contributing area, unlike solifluction lobes on Earth which are thought to require some upslope contributing area to achieve sufficient saturation (e.g., Temme and Veldkamp, 2009). Martian SSL can be much wider than terrestrial solifluction lobes, but are more often longer than terrestrial solifluction lobes (Fig. 12). Lengths that increase faster than widths is a behaviour more similar to terrestrial rock glaciers than terrestrial solifluction lobes (Matsuoka et al., 2005). It is possible that the longer time over which martian SSL can develop (due to lack of landscape disturbance by tectonics), means that they can attain much larger downslope dimensions.

We observed the length of martian SSL tends to decrease with increasing slope (Fig. 9c) whereas this trend is not apparent for lobes on Earth. We think this is likely due to the different hillslopes types between Earth and Mars. On Mars, high slopes are always located near to the crater rim, the position where most SSL originate. Over time, SSL should extend downslope, leading to an increase in their length and a decrease of the average slope. However, on Earth the hillslopes on which solifluction lobes or zebra stripe lobes develop are more diverse and consequently such a consistent signal might not develop. Moreover, we observed that in a given crater, SSL do not necessarily form on the steepest slope, which means that another factor affects the formation of SSL.

\subsection{Martian SSL and terrestrial zebra stripe lobes}

Whether formed by seismic shaking or another process, our data show that zebra stripe lobes seem to be a poor analogue for SSL on Mars compared to solifluction lobes. Although they have a similar planform shape to SSL and occur on similar slope gradients, they occur on short convex slope profiles contrary to solifluction lobes and SSL which occur on longer concave slope profiles (Fig. 12). Zebra stripe lobes can be located anywhere on the hillslope profile, whereas SSL occur near the top and solifluction lobes occur near the bottom of the profile (Fig. 9a). The dimensions of zebra stripe lobes are significantly lower than SSL and solifluction lobes (Fig. 11). Finally, zebra stripe lobes are very superficial features with low relief, they are landforms whose expression at the surface is revealed by colour-contrasts derived from clast-sorting, rather than topographic relief, in contrast to solifluction lobes and some SSL (Fig. 13). None of these individual arguments are strong enough individually to completely exclude zebra stripe lobes as a valid terrestrial analogue for SSL, but taken together we think that solifluction lobes remain the best terrestrial analogues.

\subsection{Martian SSL apparent slope constraint}

Martian SSL occur only on slopes higher than $10^{\circ}$ and rarely on slopes from $10-15^{\circ}$ (Fig. 10). In theory, the process of creep is a continuous process and should only become weaker at lower slopes, rather than cease entirely. Solifluction on Earth occurs continuously down to a few degrees of slope (Kirkbride and Dugmore, 2005; Matsuoka et al., 2005), as also shown by our data (Fig. 10). Consequently, the lobe-forming movement on Mars requires higher slope gradients than on Earth. This could be because lobes are not formed by solifluction process(es), or that solifluction operates differently on Mars to on Earth. In this section we explore how the martian conditions and environment may affect the solifluction process if it is ongoing. To assess the role of different environmental properties for the occurrence of solifluction movement, a factor of safety approach for solifluction movement can be employed following Harris et al. (2001, Eq. 1):

$$
F S=\frac{\text { Resisting forces }}{\text { Driving forces }}=\frac{c+\left(\rho g h \cos (\beta)-\rho_{w} g h^{\prime}\right) \tan (\Phi)}{\rho g h \sin (\beta)}
$$

with $F S$ factor of safety, $c$ soil cohesion, $g$ gravity, $h$ depth of the potential slip surface, $\rho$ soil density, $\rho_{w}$ water density, $h^{\prime}$ height of the piezometric surface above the slip surface, $\beta$ slope angle and $\Phi$ the 
angle of internal friction. Pore water pressures $(\mu)$ are included in the equation as the product of water density, gravity and height of the piezometric surface above the slip surface $\left(\mu=\rho_{w} g h^{\prime}\right)$. For solifluction movement to occur, driving forces must exceed resisting forces, thus, the factor of safety must become smaller than unity. Following Eq. 1, environmental properties influencing stability of solifluction slopes include gravity, soil properties (cohesion, soil density, angle of internal friction) and soil water content determining the height of the piezometric surface. Theoretical effects of these and further environmental properties (thermal regime, vegetation) on martian solifluction processes and therefore the occurrence of martian SSLs are discussed below.

\subsubsection{Effect of gravity $(g)$}

With a value of $3.71 \mathrm{~m} / \mathrm{s}^{2}$, the gravitational acceleration on Mars is about three times lower than on Earth $\left(9.81 \mathrm{~m} / \mathrm{s}^{2}\right)$. In the factor of safety, this lowered gravity $(g)$ affects both resisting and driving forces (Eq. 1). Thus, for a hillslope with self-same environmental properties, resisting and driving forces will be lower on Mars because of the lower gravity. However, the ratio between resisting and driving forces as expressed in FS stays the same as gravity affects both. Thus, on Earth and Mars the same slope gradient is required for a hillslope to become unstable and for solifluction movement to occur. Consequently, we believe it is unlikely that the lowered gravity on Mars can explain the observed slope constraint.

\subsubsection{Effects of soil properties $(c, \rho, \Phi)$, soil water content $\left(h^{\prime}\right)$ and thermal regime} Soil properties $(c, \rho, \Phi)$ included in the factor of safety depend on soil particle size and fabric (Selby, 1982). Mars' soil has a wide range of properties, reflecting the geological diversity of the surface materials (Perko et al., 2006; McGlynn et al., 2012; Meslin et al., 2013; Weitz et al., 2018), and no soil data is available for the studied solifluction sites. Thus, we can only theoretically assess the effects of soil properties on solifluction movement. All considered soil properties, cohesion, soil density and angle of internal friction, increase slope stability by increasing resisting forces (Eq. 1). Thus, if soil cohesion, density or angle of internal friction of martian soils is systematically higher than on Earth, higher slope gradients would be needed for solifluction movement to occur, which could explain the observed slope constraint. Higher cohesion could result from higher clay content, while angle of internal friction is higher for coarser material. However, it is likely that soil cohesion is generally higher on Earth than on Mars due to the contribution of organic material (e.g., Fattet et al., 2011). Hence, we consider a systematic difference in soil properties on its own unlikely to explain the difference in onset slope.

Soil water content influences the height of the piezometric surface above the slip surface $\left(h^{\prime}\right)$ and thereby determines pore water pressures $(\mu)$. Meteoric water can increase soil water content and pore water pressures and is thereby an important control on solifluction motion on Earth (Matsuoka, 2001). Melting snow, in particular increases soil water content and promotes high solifluction movement rates by increasing pore water pressures (Jaesche et al., 2003). For Mars we assume a lack of meteoric water contribution, thus, the height of the piezometric surface would depend solely on soil water content and availability during thaw, depending on the thermal regime (see below). Following the factor of safety, lower pore water pressures require e.g. a higher slope angle for hillslopes to become unstable and solifluction movement to occur. Thus, lower soil water content and/or availability, e.g. due to missing meteoric water, could therefore be a potential explanation for the observed slope threshold.

In addition, in conjunction with the thermal regime, soil properties and soil water content determine frost penetration depth and speed, formation of segregation ice and spatial distribution and thereby solifluction movement (Harris et al., 2008). Differing thermal regimes between Mars and Earth, e.g. a lower intensity of freeze-thaw action (Johnsson et al., 2018) could explain a lower intensity of 
solifluction processes and thereby the observed slope constraint. However, if this were true we might expect lobes to be less-developed on Mars, which is not the case. Interaction of soil properties, pore water pressures and thermal regime are furthermore reflected in the thaw consolidation ratio (Morgenstern and Nixon, 1971), which relates the rate of thaw and how quickly it proceeds into depth to a "coefficient of consolidation", depending on the permeability of thawed soil in relation to density of water and coefficient of compressibility. Together with soil water content, the thaw consolidation ratio influences the generation of pore water pressures $(\mu)$ during thawing, which then affect slope stability as described in the FS approach $\left(\mu=\rho_{w} g h^{\prime}\right)$. If martian soils, for example, were coarser than Earth soils and thaw more slowly, lower pore water pressures would be generated and higher slope gradients would be required for solifluction movement to occur (Eq. 1). However, in martian soil, silt-sized dust is much more common (Bell III et al., 2000; Soderblom et al., 2004) than in terrestrial soil. As silty material limits permeability and promotes ice lens development and thereby the generation of high pore water pressures, solifluction at low slope angles should be promoted rather than retarded on Mars.

\subsubsection{Vegetation and biota}

Vegetation and biota in general are clearly a differing environmental property between Mars and Earth. By affecting material and thermal properties, vegetation has numerous effects on solifluction processes (e.g., Eichel et al., 2017) and can either retard or promote solifluction movement (Matsuoka, 2001). Thus, missing vegetation and/or organic material in general could also affect solifluction movement and SSL occurrence on Mars in comparison to Earth.

Given the sparse data and large environmental heterogeneity, e.g. of soil properties, on Mars, we can only hypothesize that differing soil properties and/or thermal regime are a likely cause of the observed slope constraint. A more detailed analysis, e.g. of slope stability, which includes available data on Mars environmental properties as far as available, is needed to better understand potential solifluction processes and their effects on landform development on Mars.

\subsection{Formation of lobes by dry processes?}

The interpretation of martian SSL as solifluction lobes poses a problem for our understanding of the near surface of Mars is believed to have been very difficult due to the low humidity, atmospheric pressure and mean annual air temperature over the last $\sim \mathrm{Ga}$ (Mellon and Phillips, 2001; Kreslavsky et al., 2008). Ground ice on Mars is generally believed to have been emplaced via sublimationcondensation, rather than thaw as on Earth (e.g., Sizemore et al., 2015). Zebra stripe lobes seem to be a good analogue for martian SSL as they likely form via seismic shaking in a hyper-arid environment and we suspect that Mars is also seismically active (Roberts et al., 2012; Taylor et al., 2013; Kumar et al., 2019). However, as discussed in Section 5.2 zebra stripe lobes are actually a poor match for martian SSL in terms of plan view and 3D morphology. Lobate forms are also observed on the Moon (Fig. 14; Xiao et al., 2013), where water is not involved in slope processes. The angle of repose is the maximum angle/slope at which a material can be stable and does not slide or fall. This angle is independent of the gravitational acceleration $g$, so whether it is on Earth, Mars, or the Moon this angle is about $35^{\circ}$ (Sullivan et al., 2011; Atwood-Stone and McEwen, 2013). Lobate forms on the Moon originate at slopes $>35^{\circ}$ as shown in Fig. 14. The vast majority of martian SSL occur below this value (Fig. 10, Fig. 14), showing that they cannot be formed by a purely dry granular flow process, unlike the lobes on the Moon. In order to initiate a dry granular flow below the angle of repose lubrication is required - this could be water (as for solifluction lobes), or gas released by $\mathrm{CO}_{2}$ sublimation. 
Recent work has revealed downhill movement of boulders, typically over $<10 \mathrm{~m}$ on the same hillslopes as martian SSL (Dundas et al., 2019) and in all but one case the movements are correlated to the times of year when $\mathrm{CO}_{2}$ ice should be present. Experimental work shows that sublimation of $\mathrm{CO}_{2}$ frost can trigger creep-like motion for initial slopes ranging from 10 to $30^{\circ}$, corresponding to the slopes we measured for martian SSL (Sylvest et al., 2016, 2018). The hemispherical difference in SSL occurrence $\left(>41^{\circ} \mathrm{S}\right.$ compared to $>55^{\circ} \mathrm{N}$; Johnsson et al., 2018) could be explained by the presentday asymmetry in the occurrence of seasonal $\mathrm{CO}_{2}$ frost (Piqueux et al., 2015), which follows that of water frost (Vincendon et al., 2010). However, the exact mechanism that leads to lobe-formation under the $\mathrm{CO}_{2}$ sublimation hypothesis is unclear and requires further work in order to assess if it is consistent with the data.

\section{Conclusions}

Digital terrain models of Mars and Earth are used to measure and characterise the morphology of lobate features on both planets. We present here the first extensive three dimensional study of solifluction lobes on Earth, and the first ever 3D data for zebra stripe lobes in the Atacama Desert and SSL on Mars. Our terrestrial data show that it is important to consider that there is a diversity of periglacial environments that host solifluction lobes, where within-hillslope changes of temperature distribution, soil properties, and depth of the active layer could influence lobe-shape even at a very local scale. We find that martian SSL share almost all their morphometric characteristics with terrestrial solifluction lobes and are less similar to zebra stripe lobes, which are notably smaller in scale than SSL or solifluction lobes and located on convex hillslopes unlike SSL or solifluction lobes. We find that SSL on Mars tend to be found at steeper slopes than terrestrial analogues (averages of $\sim 16^{\circ}$ for solifluction lobes, $\sim 18.5^{\circ}$ for zebra stripe lobes and $\sim 25^{\circ}$ for SSL on Mars) with a slope gradient of at least $10^{\circ}$. We hypothesise that this constraint does not result from the lowered gravity on Mars, but could instead result from differing soil properties and/or thermal regime between Mars and Earth which affect solifluction movement. We cannot rule out a role of $\mathrm{CO}_{2}$ sublimation in lobeformation based on our terrestrial measurements.

\section{Acknowledgments}

This work was supported by the French Space Agency CNES. The data collection in Termignon, France was made possible by a loan of a Terrestrial Laser Scanner by the UK Natural Environment Research Council Geophysical Equipment Facility loan 1030. The LiDAR and aerial images for Iceland at Tindastóll were made available via the UK NERC Airborne Research Facility and funded by the European Facility for Airborne Research project "EUFAR12_02a" acronym "ICELAND_DEBRISFLOWS". The Greenland data were obtained by NERC ARF and made available via NERC Centre for Environmental Data Analysis. Access to Pléiades images of the Atacama was supported by public funds received in the framework of GEOSUD, a project (ANR-10EQPX-20) of the program "Investissements d'Avenir" managed by the French National Research Agency. The images are copyright of CNES and distributed by Airbus Defence and Space, all rights reserved. PMG was funded by the UK Space Agency (ST/R002355/1). Andreas Johnsson was supported by the Swedish National Space Agency (SNSA). We would like to thank Dr. Manuel Abad for his help in the field in the Atacama site. We thank Daniel Draebing for helpful discussions on solifluction processes. 


\section{References}

Atwood-Stone, C., McEwen, A.S., 2013. Avalanche slope angles in low-gravity environments from active Martian sand dunes. Geophys Res Lett 40, 2929-2934. https://doi.org/10.1002/grl.50586

Ballantyne, C.K., 2001. Measurement and theory of ploughing boulder movement. Permafr. Periglac. Process. 12, 267-288. https://doi.org/10.1002/ppp.389

Ballantyne, C.K., Harris, C., 1994. The Periglaciation of Great Britain. CUP Archive.

Balme, M.R., Gallagher, C.J., Hauber, E., 2013. Morphological evidence for geologically young thaw of ice on Mars: A review of recent studies using high-resolution imaging data. Prog. Phys. Geogr. 37 , 289-324. https://doi.org/10.1177/0309133313477123

Barrett, A.M., Balme, M.R., Patel, M.R., Hagermann, A., 2018. The distribution of putative periglacial landforms on the martian northern plains. Icarus 314, 133-148. https://doi.org/10.1016/j.icarus.2018.05.032

Barrett, A.M., Balme, M.R., Patel, M.R., Hagermann, A., 2017. Clastic patterned ground in Lomonosov crater, Mars: examining fracture controlled formation mechanisms. Icarus 295, 125-139. https://doi.org/10.1016/j.icarus.2017.06.008

Beaty, C., 1983. Tiger-striping; a curious form of surficial patterning in the Atacama Desert, N. Chile, in: Geological Society of America Annual Meeting Abstracts with Programs. p. 387.

Bell III, J., McSween Jr, H., Crisp, J., Morris, R., Murchie, S., Bridges, N., Johnson, J., Britt, D., Golombek, M., Moore, H., others, 2000. Mineralogic and compositional properties of Martian soil and dust: Results from Mars Pathfinder. J. Geophys. Res. Planets 105, 1721-1755. https://doi.org/10.1029/1999JE001060

Benedict, J.B., 1976. Frost creep and gelifluction features: a review. Quat. Res. 6, 55-76.

Boynton, W.V., Feldman, W., Squyres, S., Prettyman, T., Brückner, J., Evans, L., Reedy, R., Starr, R., Arnold, J., Drake, D., others, 2002. Distribution of hydrogen in the near surface of Mars: Evidence for subsurface ice deposits. science 297, 81-85. https://doi.org/10.1126/science.1073722

Bramson, A.M., Byrne, S., Putzig, N.E., Sutton, S., Plaut, J.J., Brothers, T.C., Holt, J.W., 2015. Widespread excess ice in Arcadia Planitia, Mars. Geophys. Res. Lett. 42, 6566-6574. https://doi.org/10.1002/2015GL064844

Brown, J.R., Roberts, G.P., 2019. Possible Evidence for Variation in Magnitude for Marsquakes From Fallen Boulder Populations, Grjota Valles, Mars. J. Geophys. Res. Planets 124, 801-822. https://doi.org/10.1029/2018JE005622

Buck, B.J., Rech, J., Howell, M., Prellwitz, J., Brock, A.L., 2006. A new formation process for patterned ground, Atacama Desert, Chile, in: 2006 Philadelphia Annual Meeting. The Geological Society of America. Paper.

Byrne, S., Dundas, C.M., Kennedy, M.R., Mellon, M.T., McEwen, A.S., Cull, S.C., Daubar, I.J., Shean, D.E., Seelos, K.D., Murchie, S.L., others, 2009. Distribution of mid-latitude ground ice on Mars from new impact craters. science 325, 1674-1676. https://doi.org/10.1126/science.1175307

Catling, D., Claire, M., Zahnle, K., Quinn, R., Clark, B., Hecht, M., Kounaves, S., 2010. Atmospheric origins of perchlorate on Mars and in the Atacama. J. Geophys. Res. Planets 115. https://doi.org/10.1029/2009JE003425 
Clarke, J.D., 2006. Antiquity of aridity in the Chilean Atacama Desert. Geomorphology 73, 101-114. https://doi.org/10.1016/j.geomorph.2005.06.008

Conway, S.J., Balme, M.R., Kreslavsky, M.A., Murray, J.B., Towner, M.C., 2015. The comparison of topographic long profiles of gullies on Earth to gullies on Mars: A signal of water on Mars. Icarus 253, 189-204. https://doi.org/10.1016/j.icarus.2015.03.009

Conway, S.J., Haas, T. de, Harrison, T.N., 2018. Martian gullies: a comprehensive review of observations, mechanisms and insights from Earth analogues. Geol. Soc. Lond. Spec. Publ. 467, $7-$ 66. https://doi.org/10.1144/SP467.14

De Haas, T., Hauber, E., Conway, S.J., van Steijn, H., Johnsson, A., Kleinhans, M.G., 2015. Earthlike aqueous debris-flow activity on Mars at high orbital obliquity in the last million years. Nat. Commun. 6. https://doi.org/10.1038/ncomms8543

De Haas, T., Kleinhans, M.G., Carbonneau, P.E., Rubensdotter, L., Hauber, E., 2015. Surface morphology of fans in the high-Arctic periglacial environment of Svalbard: Controls and processes. Earth-Sci. Rev. 146, 163-182. https://doi.org/10.1016/j.earscirev.2015.04.004

Draebing, D., Eichel, J., 2018. Divergence, convergence, and path dependency of paraglacial adjustment of alpine lateral moraine slopes. Land Degrad. Dev. 29, 1979-1990. https://doi.org/10.1002/ldr.2983

Dundas, C.M., Byrne, S., McEwen, A.S., Mellon, M.T., Kennedy, M.R., Daubar, I.J., Saper, L., 2014. HiRISE observations of new impact craters exposing Martian ground ice. J. Geophys. Res. Planets 119, 109-127. https://doi.org/10.1002/2013JE004482

Dundas, C.M., Mellon, M., Conway, S.J., Gastineau, R., 2019. Active boulder movement at high Martian latitudes. Geophys. Res. Lett. https://doi.org/10.1029/2019GL082293

Eichel, J., Draebing, D., Klingbeil, L., Wieland, M., Eling, C., Schmidtlein, S., Kuhlmann, H., Dikau, R., 2017. Solifluction meets vegetation: the role of biogeomorphic feedbacks for turf-banked solifluction lobe development. Earth Surf. Process. Landf. 42, 1623-1635. https://doi.org/10.1002/esp.4102

Fattet, M., Fu, Y., Ghestem, M., Ma, W., Foulonneau, M., Nespoulous, J., Le Bissonnais, Y., Stokes, A., 2011. Effects of vegetation type on soil resistance to erosion: Relationship between aggregate stability and shear strength. CATENA 87, 60-69. https://doi.org/10.1016/j.catena.2011.05.006

French, H.M., 1976. The periglacial environment. John Wiley \& Sons.

Gallagher, C., Balme, M.R., Conway, S.J., Grindrod, P.M., 2011. Sorted clastic stripes, lobes and associated gullies in high-latitude craters on Mars: Landforms indicative of very recent, polycyclic ground-ice thaw and liquid flows. Icarus 211, 458-471. https://doi.org/10.1016/j.icarus.2010.09.010

Gallagher, C.J., Balme, M.R., 2011. Landforms indicative of ground-ice thaw in the northern high latitudes of Mars. Geol. Soc. Lond. Spec. Publ. 356, 87-110. https://doi.org/10.1144/SP356.6

Harris, C., Smith, J.S., Davies, M.C., Rea, B., 2008. An investigation of periglacial slope stability in relation to soil properties based on physical modelling in the geotechnical centrifuge. Geomorphology 93, 437-459. https://doi.org/10.1016/j.geomorph.2007.03.009

Hauber, E., Reiss, D., Ulrich, M., Preusker, F., Trauthan, F., Zanetti, M., Hiesinger, H., Jaumann, R., Johansson, L., Johnsson, A., Van Gasselt, S., Olvmo, M., 2011. Landscape evolution in Martian midlatitude regions: insights from analogous periglacial landforms in Svalbard. Geol. Soc. Lond. Spec. 
600 Heimsath, A., Jungers, M., 2013. Processes, transport, deposition, and landforms: quantifying creep, 601 in: Treatise on Geomorphology. Elsevier Inc. https://doi.org/10.1016/B978-0-12-374739-6.00158-5

602 Hodgson, M.E., Bresnahan, P., 2004. Accuracy of airborne LiDAR-derived elevation. Photogramm. 603 Eng. Remote Sens. 70, 331-339. https://doi.org/10.14358/PERS.70.3.331

604 Iverson, R.M., 1997. The physics of debris flows. Rev. Geophys. 35, 245-296. 605 https://doi.org/10.1029/97RG00426

606

607

608

609

610

611

612

613

614

615

616

617

618

Jaesche, P., Veit, H., Huwe, B., 2003. Snow cover and soil moisture controls on solifluction in an area of seasonal frost, eastern Alps. Permafr. Periglac. Process. 14, 399-410. https://doi.org/10.1002/ppp.471

Johnsson, A., Conway, S.J., Reiss, D., Hauber, E., Hiesinger, H., 2018. Slow periglacial mass wasting (solifluction) on Mars, in: Dynamic Mars. Elsevier, pp. 239-269. https://doi.org/10.1016/B978-0-12813018-6.00008-X

Johnsson, A., Reiss, D., Hauber, E., Zanetti, M., Hiesinger, H., Johansson, L., Olvmo, M., 2012. Periglacial mass-wasting landforms on Mars suggestive of transient liquid water in the recent past: Insights from solifluction lobes on Svalbard. Icarus 218, 489-505. https://doi.org/10.1016/j.icarus.2011.12.021

Kessler, M., Werner, B., 2003. Self-organization of sorted patterned ground. Science 299, 380-383. https://doi.org/10.1126/science.1077309

Kirk, R., Howington-Kraus, E., Rosiek, M., Anderson, J., Archinal, B., Becker, K., Cook, D., Galuszka, D., Geissler, P., Hare, T., others, 2008. Ultrahigh resolution topographic mapping of Mars with MRO HiRISE stereo images: Meter-scale slopes of candidate Phoenix landing sites. J. Geophys. Res. Planets 113. https://doi.org/10.1029/2007JE003000

Kirkbride, M.P., Dugmore, A.J., 2005. Late Holocene solifluction history reconstructed using tephrochronology. Geol. Soc. Lond. Spec. Publ. 242, 145-155. https://doi.org/10.1144/GSL.SP.2005.242.01.13

Kreslavsky, M., Head, J., 2003. North-south topographic slope asymmetry on Mars: Evidence for insolation-related erosion at high obliquity. Geophys. Res. Lett. 30. https://doi.org/10.1029/2003GL017795

Kreslavsky, M.A., Head, J.W., Marchant, D.R., 2008. Periods of active permafrost layer formation during the geological history of Mars: Implications for circum-polar and mid-latitude surface processes. Planet. Space Sci. 56, 289-302. https://doi.org/10.1016/j.pss.2006.02.010

Kumar, P.S., Krishna, N., Lakshmi, K.P., Raghukanth, S., Dhabu, A., Platz, T., 2019. Recent seismicity in Valles Marineris, Mars: Insights from young faults, landslides, boulder falls and possible mud volcanoes. Earth Planet. Sci. Lett. 505, 51-64. https://doi.org/10.1016/j.epsl.2018.10.008

Laskar, J., Correia, A., Gastineau, M., Joutel, F., Levrard, B., Robutel, P., 2004. Long term evolution and chaotic diffusion of the insolation quantities of Mars. Icarus 170, 343-364. https://doi.org/10.1016/j.icarus.2004.04.005

Levy, J., Head, J., Marchant, D., 2009. Thermal contraction crack polygons on Mars: Classification, distribution, and climate implications from HiRISE observations. J. Geophys. Res. Planets 114. https://doi.org/10.1029/2008JE003273 
Li, A., Matsuoka, N., Niu, F., 2018. Frost sorting on slopes by needle ice: A laboratory simulation on the effect of slope gradient. Earth Surf. Process. Landf. 43, 685-694. https://doi.org/10.1002/esp.4276

Mangold, N., 2005. High latitude patterned grounds on Mars: Classification, distribution and climatic control. Icarus 174, 336-359. https://doi.org/10.1016/j.icarus.2004.07.030

Mangold, N., Maurice, S., Feldman, W., Costard, F., Forget, F., 2004. Spatial relationships between patterned ground and ground ice detected by the Neutron Spectrometer on Mars. J. Geophys. Res. Planets 109. https://doi.org/10.1029/2004JE002235

Marion, G., Catling, D., Zahnle, K., Claire, M., 2010. Modeling aqueous perchlorate chemistries with applications to Mars. Icarus 207, 675-685. https://doi.org/10.1016/j.icarus.2009.12.003

Matmon, A., Quade, J., Placzek, C., Fink, D., Arnold, M., Aumaitre, G., Bourlès, D., Keddadouche,

K., Copeland, A., Neilson, J., 2015. Seismic origin of the Atacama Des
Geomorphology 231, 28-39. https://doi.org/10.1016/j.geomorph.2014.11.008

Matsuoka, N., 2001. Solifluction rates, processes and landforms: a global review. Earth-Sci. Rev. 55, 107-134. https://doi.org/10.1016/S0012-8252(01)00057-5

Matsuoka, N., 1998. The relationship between frost heave and downslope soil movement: field measurements in the Japanese Alps. Permafr. Periglac. Process. 9, 121-133. https://doi.org/10.1002/(SICI)1099-1530(199804/06)9:2<121::AID-PPP281>3.3.CO;2-3

Matsuoka, N., Ikeda, A., Date, T., 2005. Morphometric analysis of solifluction lobes and rock glaciers in the Swiss Alps. Permafr. Periglac. Process. 16, 99-113. https://doi.org/10.1002/ppp.517

May, S.M., Hoffmeister, D., Wolf, D., Bubenzer, O., 2019. Zebra stripes in the Atacama Desert revisited - Granular fingering as a mechanism for zebra stripe formation? Geomorphology 344, 4659. https://doi.org/10.1016/j.geomorph.2019.07.014

McGlynn, I.O., Fedo, C.M., McSween, H.Y., 2012. Soil mineralogy at the Mars Exploration Rover landing sites: An assessment of the competing roles of physical sorting and chemical weathering. J. Geophys. Res. Planets 117. https://doi.org/10.1029/2011JE003861

Mellon, M.T., Phillips, R.J., 2001. Recent gullies on Mars and the source of liquid water. J. Geophys. Res. Planets 106, 23165-23179. https://doi.org/10.1029/2000JE001424

Meslin, P.-Y., Gasnault, O., Forni, O., Schröder, S., Cousin, A., Berger, G., Clegg, S., Lasue, J., Maurice, S., Sautter, V., others, 2013. Soil diversity and hydration as observed by ChemCam at Gale Crater, Mars. Science 341, 1238670. https://doi.org/10.1126/science.1238670

Morgenstern, N.R., Nixon, J.F., 1971. One-dimensional Consolidation of Thawing Soils. Can. Geotech. J. 8, 558-565. https://doi.org/10.1139/t71-057

Mouginot, J., Pommerol, A., Kofman, W., Beck, P., Schmitt, B., Herique, A., Grima, C., Safaeinili, A., Plaut, J.J., 2010. The 3-5MHz global reflectivity map of Mars by MARSIS/Mars Express: Implications for the current inventory of subsurface H2O. Icarus 210, 612-625. https://doi.org/10.1016/j.icarus.2010.07.003

Nyström, E., 2015. Observations of Putative Freeze-thaw Landforms on Mars Northern Hemisphere. Bachelor of Science thesis. University of Gothenburg. Department of Earth Sciences Geovetarcentrum/Earth Science Centre. Sweden.

Nyström, E., Johnsson, A., 2014. Aspect dependence of small-scale lobes in the Northern Hemisphere 
on Mars, in: European Planetary Science Congress.

681 Ojha, L., Wilhelm, M.B., Murchie, S.L., McEwen, A.S., Wray, J.J., Hanley, J., Massé, M., Chojnacki, 682 M., 2015. Spectral evidence for hydrated salts in recurring slope lineae on Mars. Nat Geosci 8, 829683 832. https://doi.org/10.1038/ngeo2546

684 Owen, J.J., Dietrich, W.E., Nishiizumi, K., Chong, G., Amundson, R., 2013. Zebra stripes in the 685 Atacama Desert: Fossil evidence of overland flow. Geomorphology 182, 157-172. 686 https://doi.org/10.1016/j.geomorph.2012.11.006

687 Pathare, A.V., Feldman, W.C., Prettyman, T.H., Maurice, S., 2018. Driven by excess? Climatic 688 implications of new global mapping of near-surface water-equivalent hydrogen on Mars. Icarus 301, 689 97-116. https://doi.org/10.1016/j.icarus.2017.09.031

690 Pawlik, Ł., Šamonil, P., 2018. Soil creep: The driving factors, evidence and significance for 691 biogeomorphic and pedogenic domains and systems - A critical literature review. Earth-Sci. Rev. 692 178, 257-278. https://doi.org/10.1016/j.earscirev.2018.01.008

693 Perko, H.A., Nelson, J.D., Green, J.R., 2006. Mars soil mechanical properties and suitability of Mars 694 soil simulants. J. Aerosp. Eng. 19, 169-176. https://doi.org/10.1061/(ASCE)0893695 1321(2006)19:3(169)

696

697

698

699

700

701

702

703

704

705

706

707

708

709

710

711

712

713

714

715

716

717

718

719

Pestova, O., Myund, L., Khripun, M., Prigaro, A., 2005. Polythermal study of the systems M (ClO 4) 2-H $2 \mathrm{O}(\mathrm{M} \mathrm{2+=} \mathrm{Mg} \mathrm{2+,} \mathrm{Ca} \mathrm{2+,} \mathrm{Sr} \mathrm{2+,} \mathrm{Ba} \mathrm{2+).} \mathrm{Russ.} \mathrm{J.} \mathrm{Appl.} \mathrm{Chem.} \mathrm{78,} \mathrm{409-413.}$ https://doi.org/10.1007/s11167-005-0306-Z

Piqueux, S., Kleinböhl, A., Hayne, P.O., Kass, D.M., Schofield, J.T., McCleese, D.J., 2015. Variability of the martian seasonal CO2 cap extent over eight Mars Years. Icarus 251, 164-180. https://doi.org/10.1016/j.icarus.2014.10.045

Reiss, D., Van Gasselt, S., Neukum, G., Jaumann, R., 2004. Absolute dune ages and implications for the time of formation of gullies in Nirgal Vallis, Mars. J. Geophys. Res. Planets 109. https://doi.org/10.1029/2004JE002251

Richardson, M.I., Mischna, M.A., 2005. Long-term evolution of transient liquid water on Mars. J. Geophys. Res. Planets 110. https://doi.org/10.1029/2004JE002367

Roberts, G.P., Matthews, B., Bristow, C., Guerrieri, L., Vetterlein, J., 2012. Possible evidence of paleomarsquakes from fallen boulder populations, Cerberus Fossae, Mars. J. Geophys. Res. Planets 117. https://doi.org/10.1029/2011JE003816

Rummel, J.D., Beaty, D.W., Jones, M.A., Bakermans, C., Barlow, N.G., Boston, P.J., Chevrier, V.F., Clark, B.C., de Vera, J.-P.P., Gough, R.V., others, 2014. A new analysis of Mars "special regions": findings of the second MEPAG Special Regions Science Analysis Group (SR-SAG2). https://doi.org/10.1089/ast.2014.1227

Schon, S.C., Head, J.W., Fassett, C.I., 2009. Unique chronostratigraphic marker in depositional fan stratigraphy on Mars: Evidence for ca. 1.25 Ma gully activity and surficial meltwater origin. Geology 37, 207-210. https://doi.org/10.1130/G25398A.1

Selby, M.J., 1982. Hillslope materials and processes.

Sizemore, H.G., Zent, A.P., Rempel, A.W., 2015. Initiation and growth of martian ice lenses. Icarus 251, 191-210. https://doi.org/10.1016/j.icarus.2014.04.013 
Slaymaker, O., 2011. Criteria to Distinguish Between Periglacial, Proglacial and Paraglacial Environments. Quaest. Geogr. 30. https://doi.org/10.2478/v10117-011-0008-y

Smith, D.J., 1988. Rates and controls of soil movement on a solifluction slope in the Mount Rae area, Canadian Rocky Mountains. Z. Für Geomorphol. NF 71, 25-44.

Soare, R., Conway, S., Gallagher, C., Dohm, J., 2016. Sorted (clastic) polygons in the Argyre region, Mars, and possible evidence of pre-and post-glacial periglaciation in the Late Amazonian Epoch. Icarus 264, 184-197. https://doi.org/10.1016/j.icarus.2015.09.019

Soderblom, L.A., Anderson, R.C., Arvidson, R.E., Bell, J., Cabrol, N.A., Calvin, W., Christensen, P.R., Clark, B.C., Economou, T., Ehlmann, B.L., others, 2004. Soils of Eagle crater and Meridiani Planum at the Opportunity rover landing site. Science 306, 1723-1726. https://doi.org/10.1126/science.1105127

Stuurman, C., Osinski, G., Holt, J., Levy, J., Brothers, T., Kerrigan, M., Campbell, B., 2016. SHARAD detection and characterization of subsurface water ice deposits in Utopia Planitia, Mars. Geophys. Res. Lett. 43, 9484-9491. https://doi.org/10.1002/2016GL070138

Sullivan, R., Anderson, R., Biesiadecki, J., Bond, T., Stewart, H., 2011. Cohesions, friction angles, and other physical properties of Martian regolith from Mars Exploration Rover wheel trenches and wheel scuffs. J. Geophys. Res. Planets 116. https://doi.org/10.1029/2010JE003625

Sylvest, M.E., Conway, S.J., Patel, M.R., Dixon, J.C., Barnes, A., 2016. Mass wasting triggered by seasonal $\mathrm{CO} 2$ sublimation under Martian atmospheric conditions: Laboratory experiments. Geophys. Res. Lett. 43. https://doi.org/10.1002/2016GL071022

Sylvest, M.E., Dixon, J.C., Conway, S.J., Patel, M.R., McElwaine, J.N., Hagermann, A., Barnes, A., 2018. CO2 sublimation in Martian gullies: laboratory experiments at varied slope angle and regolith grain sizes. Geol. Soc. Lond. Spec. Publ. 467, SP467-11. https://doi.org/10.1144/SP467.11

Taylor, J., Teanby, N., Wookey, J., 2013. Estimates of seismic activity in the Cerberus Fossae region of Mars. J. Geophys. Res. Planets 118, 2570-2581. https://doi.org/10.1002/2013JE004469

Temme, A., Veldkamp, A., 2009. Multi-process Late Quaternary landscape evolution modelling reveals lags in climate response over small spatial scales. Earth Surf. Process. Landf. 34, 573-589. https://doi.org/10.1002/esp.1758

Vincendon, M., Forget, F., Mustard, J., 2010. Water ice at low to midlatitudes on Mars. J. Geophys. Res. Planets 115. https://doi.org/10.1029/2010JE003584

Weitz, C.M., Sullivan, R.J., Lapotre, M.G., Rowland, S.K., Grant, J.A., Baker, M., Yingst, R.A., 2018. Sand grain sizes and shapes in eolian bedforms at Gale crater, Mars. Geophys. Res. Lett. 45, 9471-9479. https://doi.org/10.1029/2018GL078972

Xiao, Z., Zeng, Z., Ding, N., Molaro, J., 2013. Mass wasting features on the Moon-how active is the lunar surface? Earth Planet. Sci. Lett. 376, 1-11. https://doi.org/10.1016/j.epsl.2013.06.015 
Table 1: Stereo pairs hosting SSL. Rows highlighted in grey indicate DTMs produced during this study. The number in the "Study" column represents data from: l= Nyström (2015); 2= Gallagher et al., (2011); 3= Johnsson et al., (2012); 4= Johnsson et al., (2018); $5=$ this study

\begin{tabular}{|c|c|c|c|c|c|c|c|c|}
\hline Study & Image 1 & Image 2 & Latitude $\left(^{\circ}\right)$ & Longitude $\left({ }^{\circ} \mathbf{E}\right)$ & Emergence angle between pair & $\begin{array}{l}\text { Time between images } \\
\text { (approximately) }\end{array}$ & DTM name & Vertical precision (m) \\
\hline 1 & ESP_025668_2390 & ESP_026314_2390 & 58.66 & 217.244 & 21.1 & 2 months & L_58_217 & 0.17 \\
\hline 1 & $\overline{\text { ESP_025888_2365 }}$ & $\overline{\text { ESP_025664_2365 }}$ & 56.401 & 327.271 & 29.3 & 15 days & L_56_327 & 0.13 \\
\hline 1 & ESP $026888 \quad 2550$ & ESP $026585 \quad 2550$ & 74.874 & 14.898 & 21.7 & 1 month & & 0.18 \\
\hline 1 & ESP $026880 \quad 2355$ & ESP_026959 2355 & 55.323 & 253.551 & 21.3 & 6 days & & 0.17 \\
\hline 1 & ESP_026564_2405 & ESP_027065_2405 & 60.202 & 236.27 & 16.2 & 1 month & L_60_236 & 0.22 \\
\hline 1 & ESP_026538 2420 & ESP $018758 \quad 2420$ & 61.706 & 229.053 & 18.6 & 4 months & & 0.39 \\
\hline 1 & ESP $026455 \quad 2460$ & ESP_025901_2460 & 65.768 & 334.797 & 22.8 & 1.5 months & L_65_334 & 0.16 \\
\hline 1 & ESP_026828_2420 & ESP_026907_2420 & 61.689 & 228.7 & 18.2 & 7 days & & 0.19 \\
\hline 1 & ESP_027197_2420 & ESP_016279_2420 & 61.728 & 229.235 & 28.5 & 4 months & & 0.13 \\
\hline 1 & ESP_027851_2410 & ESP_027073 2410 & 60.483 & 20.794 & 12.7 & 2 months & & 0.28 \\
\hline 1 & ESP $035233 \quad 2395$ & ESP $034890 \quad 2395$ & 58.994 & 85.86 & 26.6 & 26 days & & 0.27 \\
\hline 2 & PSP $010846 \quad 2485$ & PSP $010648 \quad 2485$ & 68.346 & 235.715 & 24.8 & 15 days & & 0.14 \\
\hline 3 & PSP $010800 \quad 2535$ & PSP 010787 2535 & 73.31 & 39.09 & 15.3 & 1 day & & 0.25 \\
\hline 3 & PSP_008141_2440 & PSP_007429_2440 & 63.78 & 292.32 & 10.2 & 2 months & L_63_292 & 0.35 \\
\hline 3 & 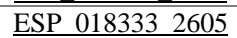 & $\begin{array}{lll}\text { ESP } 018926 \quad 2605 \\
\end{array}$ & 80.2 & 295.8 & 17 & 1.5 months & & 0.46 \\
\hline 3 & ESP $018656 \quad 2455$ & ESP $018010 \quad 2455$ & 65.4 & 128.4 & 15.8 & 2 months & & 0.47 \\
\hline 3 & ESP_019147_2395 & ESP_018712_2395 & 59.4 & 44.4 & 19.6 & 1 month & L_59_44 & 0.38 \\
\hline 4 & ESP $042941 \quad 1370$ & $\begin{array}{lll}\text { ESP } & 028726 & 1370\end{array}$ & -42.442 & 271.488 & 2.3 & 3 years & & 2.50 \\
\hline 4 & ESP $041013 \quad 1370$ & ESP $023211 \_1370$ & -42.67 & 349.906 & 5.6 & 4 years & & 0.52 \\
\hline 4 & ESP_021686_1360 & ESP_024086_1360 & -43.891 & 222.536 & 29 & 6 months & & 0.10 \\
\hline 4 & ESP_032928_1340 & ESP_024080_1340 & -45.422 & 25.74 & 15.4 & 2 years & & 0.39 \\
\hline 4 & ESP $024318 \quad 1335$ & ESP $013624 \quad 1335$ & -45.922 & 9.542 & 12 & 2.5 years & L_-45_9 & 0.24 \\
\hline 4 & $\begin{array}{l}\text { ESP } 037378 \quad 1335 \\
\end{array}$ & ESP_028583_1335 & -46.015 & 216.553 & 10.8 & 2 years & & 1.07 \\
\hline 4 & ESP_021870_1315 & ESP_021514_1315 & -48.106 & 242.441 & 3.7 & 1 month & & 0.77 \\
\hline 4 & ESP_012574_1270 & ESP_012996_1270 & -52.878 & 234.703 & 9.8 & 1 month & & 0.29 \\
\hline 4 & ESP 022481 1230 & ESP $022613 \quad 1230$ & -56.911 & 123.191 & 25.8 & 10 days & & 0.23 \\
\hline 4 & ESP_029058_1160 & ESP_028636_1160 & -63.513 & 212.059 & 9.2 & 1 month & & 0.62 \\
\hline 4 & ESP $028425 \quad 1160$ & ESP $022491 \quad 1160$ & -63.68 & 212.104 & 3.9 & 1 year & & 1.47 \\
\hline 4 & ESP $023513 \quad 1105$ & ESP $023460 \quad 1105$ & -69.254 & 38.273 & 33.7 & 4 days & & 0.17 \\
\hline 4 & $\begin{array}{l}\text { ESP } 013923 \quad 1055 \\
\end{array}$ & $\begin{array}{l}\text { ESP_013699_1055 } \\
\end{array}$ & -74.199 & 130.57 & 16.3 & 18 days & & 0.34 \\
\hline 5 & ESP_048715_1220 & ESP_048794_1220 & -57.679 & 318.317 & 23.2 & 6 days & & 0.12 \\
\hline 5 & PSP $009935 \quad 2505$ & PSP $009803 \quad 2505$ & 70.286 & 266.248 & 14.5 & 10 days & & 0.50 \\
\hline 5 & ESP $014104 \quad 1360$ & ESP_021686_1360 & -43.885 & 222.514 & 24.1 & 2 years & & 0.13 \\
\hline
\end{tabular}


762 Table 2: Characteristics and location for each martian DTM generated for this study.

\begin{tabular}{|c|c|c|c|c|c|c|c|}
\hline Stereo pairs & Latitude & Longitude & Description & $\begin{array}{l}\text { Emergence } \\
\text { angle }\end{array}$ & $\begin{array}{c}\text { Time } \\
\text { between } \\
\text { images }\end{array}$ & Site name & $\begin{array}{l}\text { Crater } \\
\text { diameter } \\
(\mathbf{k m})\end{array}$ \\
\hline ESP_025668_2390 & $58.66^{\circ} \mathrm{N}$ & $217.24^{\circ} \mathrm{E}$ & Sorted lobes & $21.1^{\circ}$ & 2 months & L_58_217 & \\
\hline ESP_026314_2390 & & & $\begin{array}{l}\text { associated with small } \\
\text { gullies, clast stripes } \\
\text { and polygons. }\end{array}$ & & & & 1.8 \\
\hline $\begin{array}{l}\text { ESP_025888_2365 } \\
\text { ESP_025664_2365 }\end{array}$ & $56.40^{\circ} \mathrm{N}$ & $327.27^{\circ} \mathrm{E}$ & $\begin{array}{c}\text { Sorted lobes, gullies, } \\
\text { polygons }\end{array}$ & $29.3^{\circ}$ & 15 days & L_56_327 & 3.5 \\
\hline $\begin{array}{l}\text { ESP_026564_2405 } \\
\text { ESP_027065_2405 }\end{array}$ & $60.20^{\circ} \mathrm{N}$ & $236.27^{\circ} \mathrm{E}$ & $\begin{array}{l}\text { Sorted lobes } \\
\text { associated with } \\
\text { gullies. }\end{array}$ & $16.2^{\circ}$ & 1 month & L_60_236 & 3.1 \\
\hline $\begin{array}{l}\text { ESP_026455_2460 } \\
\text { ESP_025901_2460 }\end{array}$ & $65.77^{\circ} \mathrm{N}$ & $334.80^{\circ} \mathrm{E}$ & $\begin{array}{l}\text { Sorted lobes, small } \\
\text { gullies, clast stripes } \\
\text { and polygons. }\end{array}$ & $22.8^{\circ}$ & 1.5 months & L_65_334 & 4.2 \\
\hline $\begin{array}{l}\text { ESP_027768_2525 } \\
\text { ESP_027860_2525 }\end{array}$ & $72.44^{\circ} \mathrm{N}$ & $126.46^{\circ} \mathrm{E}$ & $\begin{array}{l}\text { Sorted lobes and } \\
\text { polygons. }\end{array}$ & $29.4^{\circ}$ & 7 days & L_72_126 & 2.0 \\
\hline $\begin{array}{l}\text { PSP_008141_2440 } \\
\text { PSP_007429_2440 }\end{array}$ & $63.78^{\circ} \mathrm{N}$ & $292.32^{\circ} \mathrm{E}$ & $\begin{array}{l}\text { Sorted lobes, gullies, } \\
\text { retrogressive thaw } \\
\text { slump-like form in } \\
\text { gully and polygons. }\end{array}$ & $10.2^{\circ}$ & 2 months & L_63_292 & 16.6 \\
\hline $\begin{array}{l}\text { ESP_019147_2395 } \\
\text { ESP_018712_2395 }\end{array}$ & $59.40^{\circ} \mathrm{N}$ & $44.40^{\circ} \mathrm{E}$ & $\begin{array}{l}\text { Sorted lobes, gullies } \\
\text { and clast stripes }\end{array}$ & $19.6^{\circ}$ & 1 month & L_59_44 & 3.5 \\
\hline $\begin{array}{l}\text { ESP_024318_1335 } \\
\text { ESP_013624_1335 }\end{array}$ & $45.92^{\circ} \mathrm{S}$ & $9.54^{\circ} \mathrm{E}$ & $\begin{array}{l}\text { Clast-banked lobes on } \\
\text { S-facing slope in close } \\
\text { spatial proximity to } \\
\text { gully and polygons. }\end{array}$ & $12^{\circ}$ & 2.5 years & L_-45_9 & $\begin{array}{c}3.1 \\
\text { Tivat crater }\end{array}$ \\
\hline
\end{tabular}


764 Table 3: Terrestrial datasets used in this study.

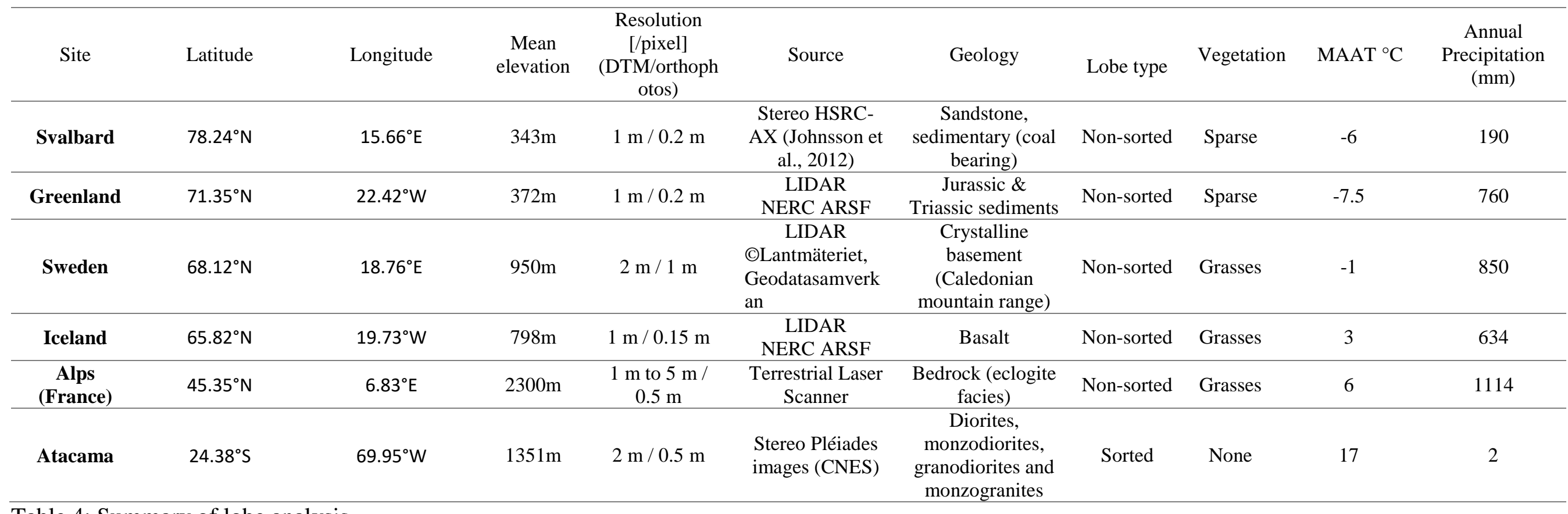

765 Table 4: Summary of lobe analysis.

\begin{tabular}{|c|c|c|c|}
\hline \multicolumn{2}{|c|}{ Earth } & \multicolumn{2}{|c|}{ Mars } \\
\hline Site & Number of lobes & Site & Number of lobes \\
\hline Sweden & 1374 & L_65_334 & 136767 \\
\hline Iceland & 730 & L_63_292 & 537 \\
\hline Alps & 174 & L_60_236 & $237^{100}$ \\
\hline Greenland & 140 & L_-45_9 & 62 \\
\hline Svalbard & 341 & L_72_126 & 288 \\
\hline Atacama & 488 & L_59_44 & 398 \\
\hline & & L_56_327 & 84 \\
\hline & & L_58_217 & 159 \\
\hline Subtotal & 3247 & Subtotal & 1901772 \\
\hline & TOTAL & 5148 & \\
\hline
\end{tabular}




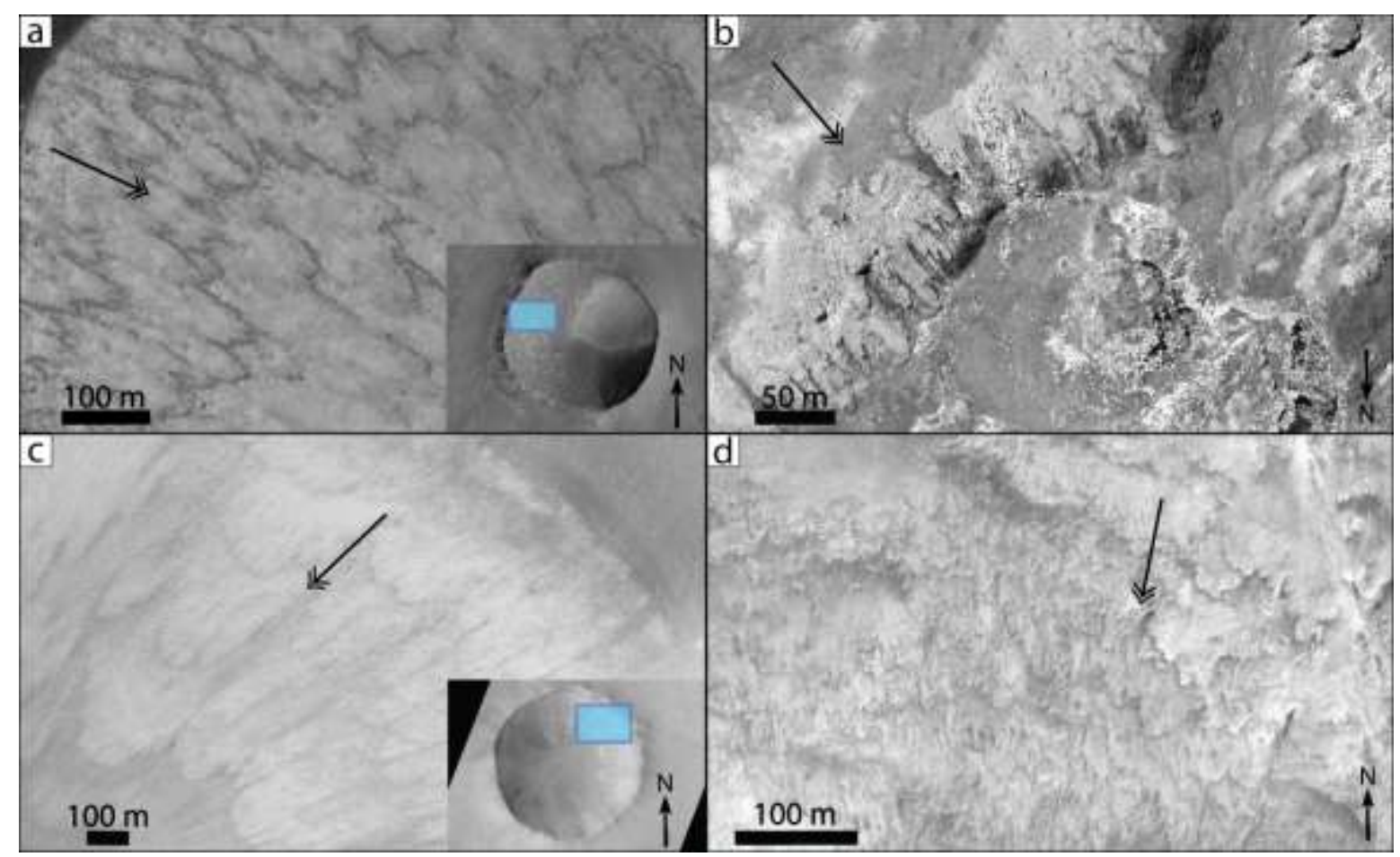

774

775

776

777

778

779

780

781

Fig. 1: Examples of martian Small Scale Lobes (SSL) and terrestrial lobes. Double-headed arrows indicate downslope direction. a) Sorted martian SSL in the northern hemisphere, in a 1-kilometrecrater. HiRISE image: ESP_027768_2525. $72.44^{\circ} \mathrm{N}, 126.46^{\circ} \mathrm{E}$. Inset shows the position of the main image (blue box) within the crater. b) Non-sorted solifluction lobes near Termignon in the French Alps, France. Credit: IGN BD ORTHO. c) Non-sorted SSL in a 4-km-crater on Mars. HiRISE image: ESP_026455_2460. $65.77^{\circ} \mathrm{N}, 334.80^{\circ} \mathrm{E}$. Inset shows the position of the main image (blue box) within the crater. d) Non-sorted solifluction lobes located on Tindastóll, Iceland. Credit: NERC ARSF. Note the similarity in scale and shape between lobes on Mars and on Earth.

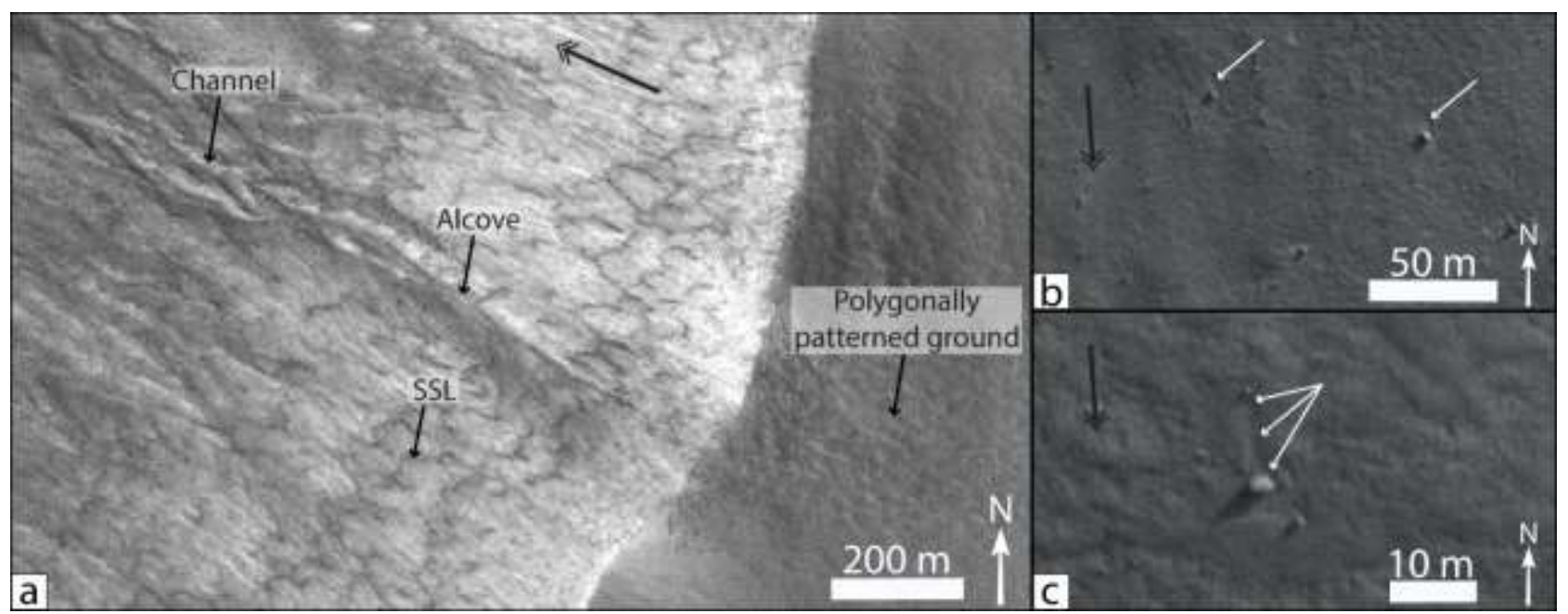

Fig. 2: Martian Small Scale Lobes (SSL), gullies and ploughing boulders. Double-headed arrows indicate downslope direction. (a) HiRISE image PSP_008141_2440 (site L_63_292) showing the spatial proximity of gully alcoves and channels, SSL and polygonally patterned ground. Panels (b) and (c) show ploughing boulders on the exterior slope of a high latitude crater. On Earth, these features are strongly associated with solifluction. White arrows indicate the furrow behind the boulder. HiRISE image: ESP_017626_2825. 
(a)

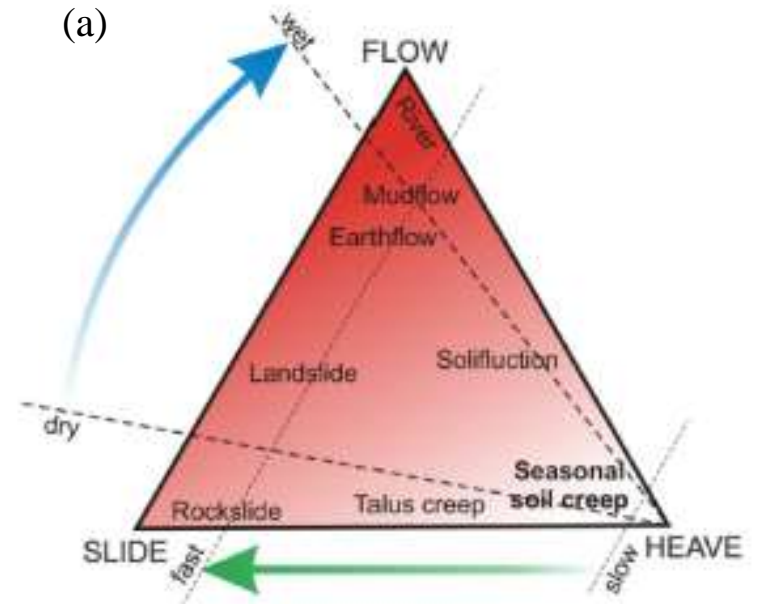

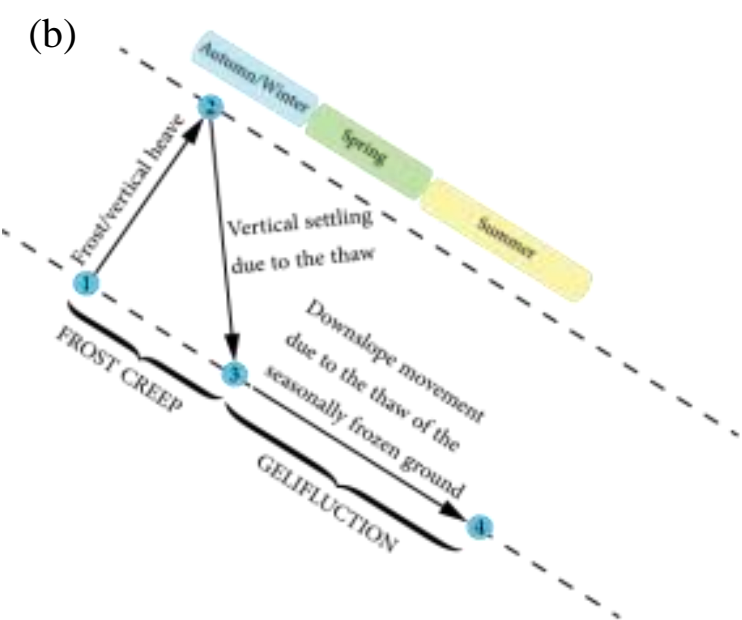

Fig. 3: (a) Classification of surface processes according to their velocity and water content (from Pawlik and Šamonil, 2018). (b) Simplified diagram outlining the processes contributing to the solifluction processes.

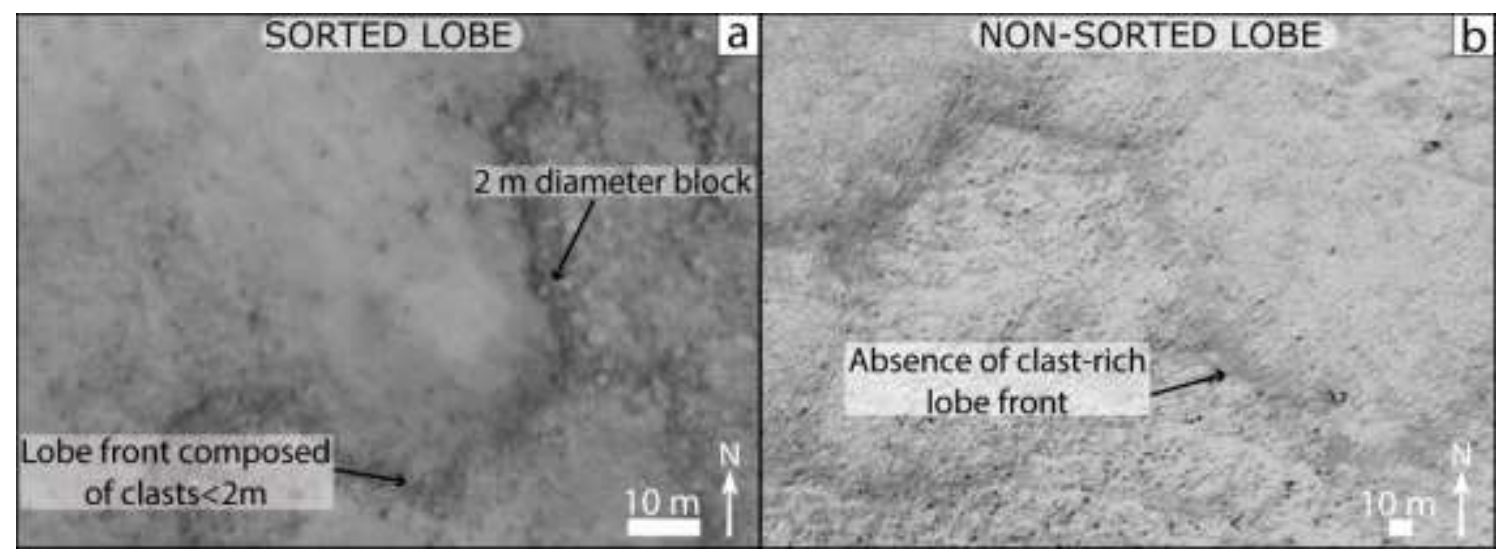

Fig. 4: Sorted and non-sorted Small Scale Lobes (SSL) on Mars. (a) HiRISE image ESP_027860_2525 showing sorted lobes banked by large clasts. (b) HiRISE image PSP_007832_2410 showing non-sorted lobes where the risers are not demarked by clasts, but are visible because of their relief. 


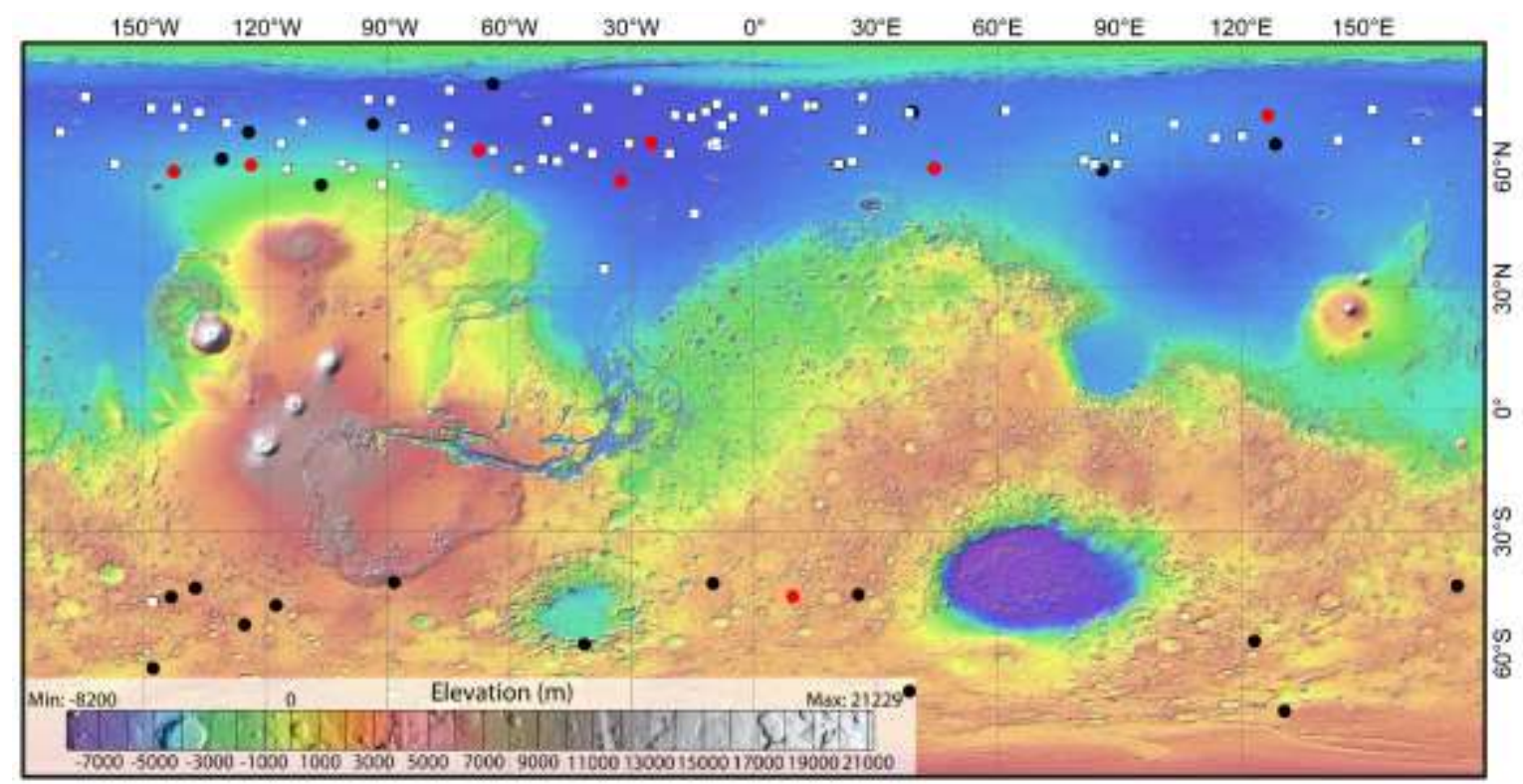

816

817 Fig. 5: Locations of HiRISE images with Small Scale Lobes. White squares are HiRISE images and 818 black points are stereo pairs, hosting SSL (based on Johnsson et al., 2018). Red points are DTMs used 819 in this study. The global map of Mars is generated using colourised Mars Orbiter Laser Altimeter 820 (MOLA) elevation data overlain by hillshaded relief.

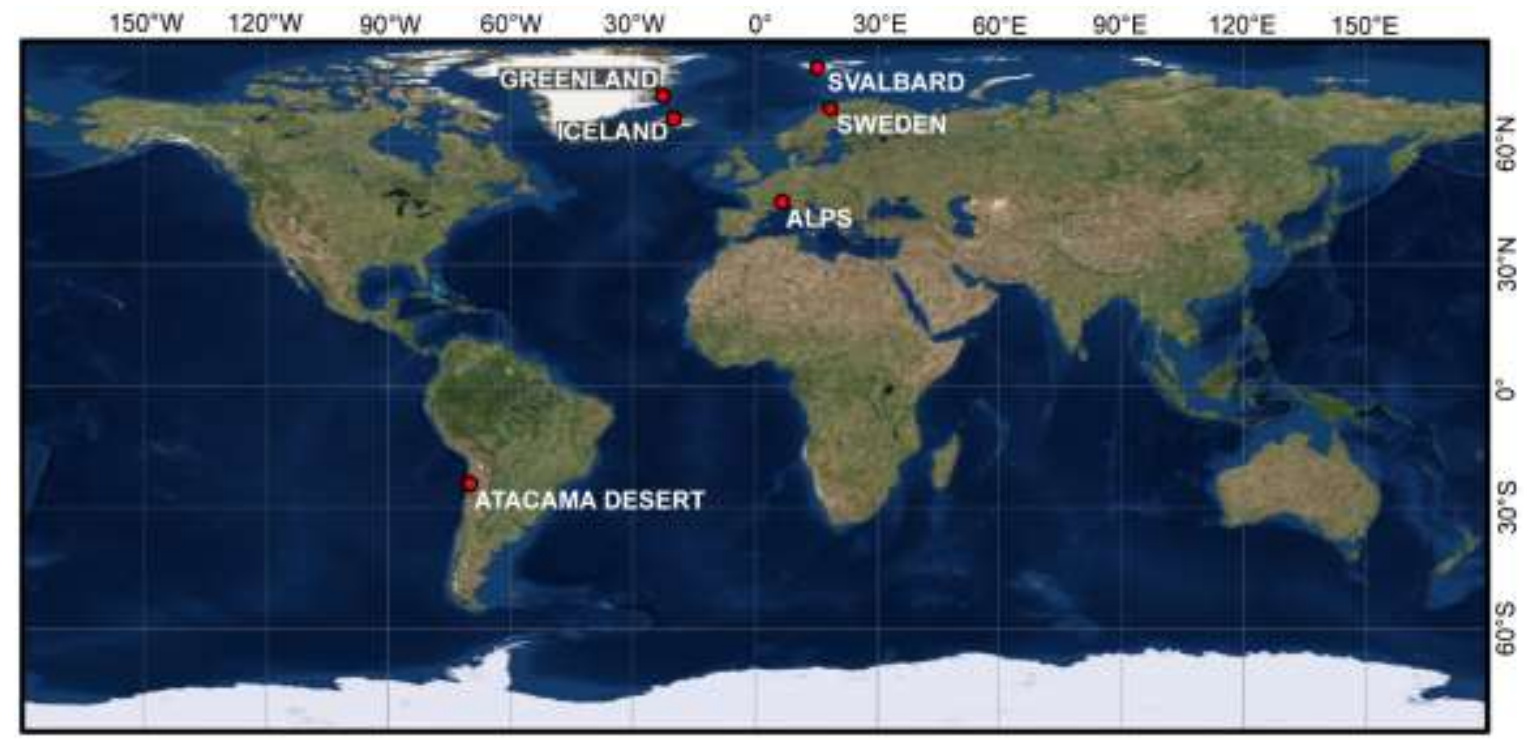

822 Fig. 6: World map showing the location of the terrestrial analogues used in this study. 


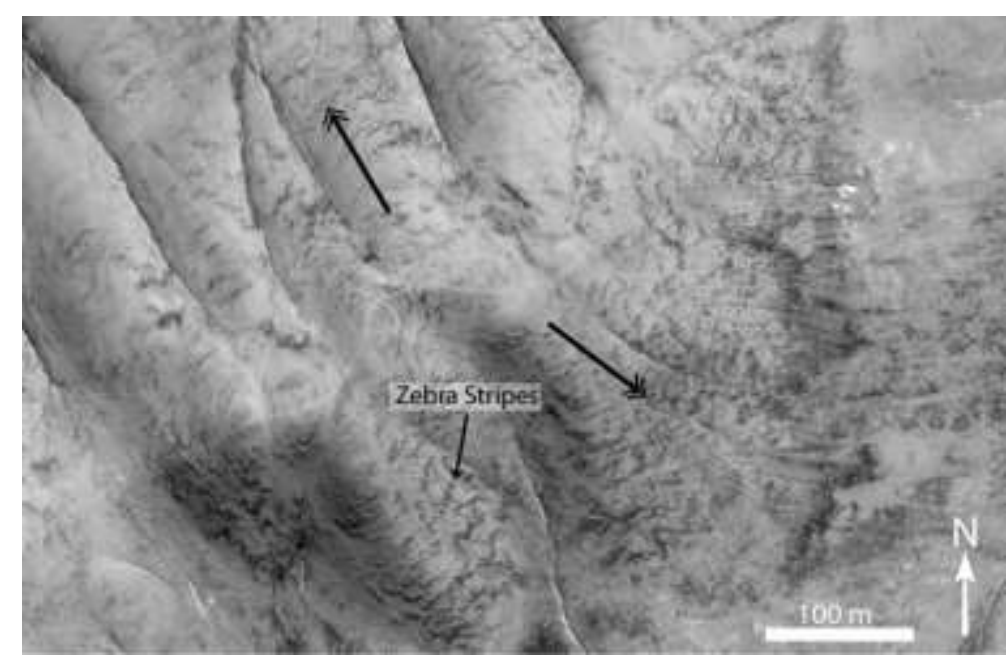

Fig. 7: Pléiades orthophoto showing zebra stripe lobes on hillslopes, in the Atacama Desert. $24^{\circ} 14^{\prime} \mathrm{S}, 6^{\circ} 54^{\prime} \mathrm{W}$. Double-headed arrows indicate the downslope directions.

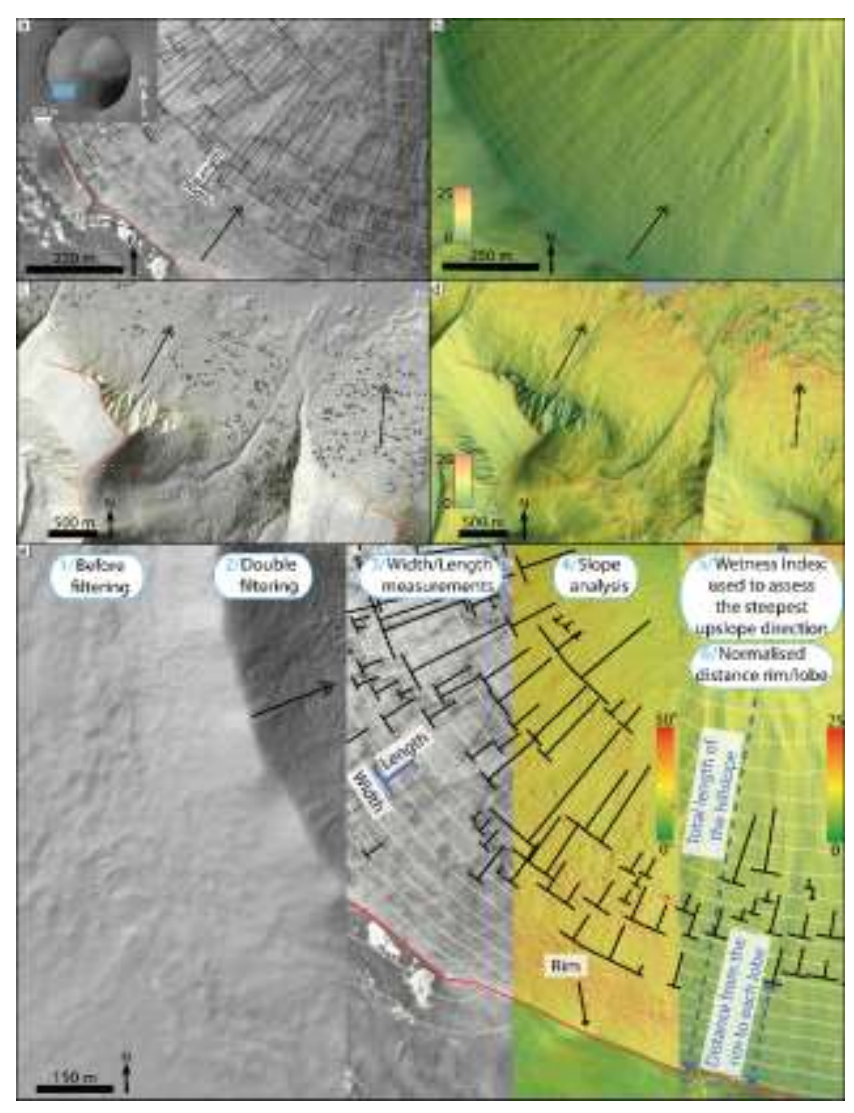

Fig. 8: Images illustrating the method used for lobe measurements and identification of the nearest upslope ridge. Double-headed arrow indicates the downslope direction. Panels (a) and (c): downslope and cross-slope dimensions of lobes (in black) digitised on the orthoimage for martian site L_72_126 and on a hillshaded relief map of the Sweden DTM (Elevation data 2m, raster (C) Lantmäteriet, Geodatasamverkan), respectively. The nearest upslope ridge is shown in red. Panels (b) and (d): colour-coded map of the "compound topographic index" (a visualisation tool, allowing the identification of the orientation of the steepest downslope/upslope direction and the local ridges in the terrain) and overlain hillshaded relief map were used to identify the nearest upslope ridge and digitise it (red lines). Panel (e): Sketch outlining the main steps undertaken in our GIS analysis. 

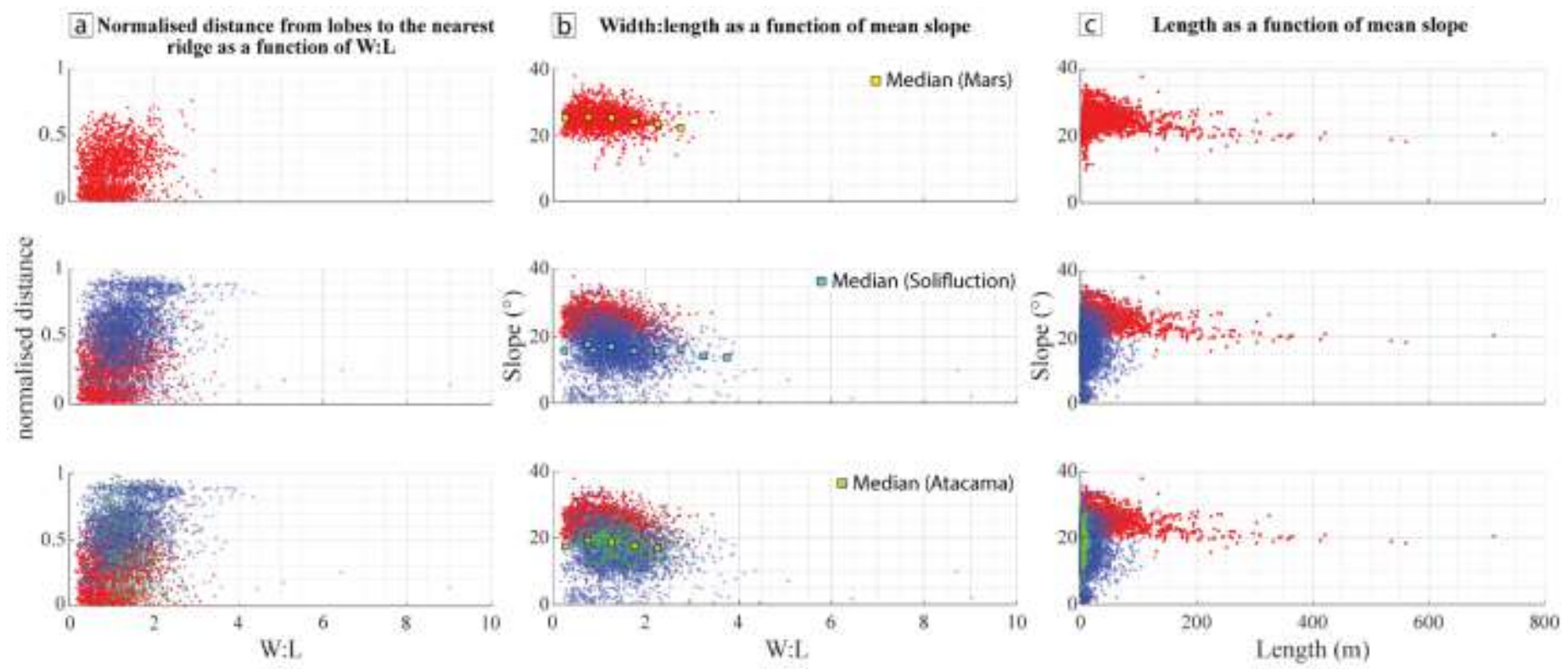

Fig. 9: (a) Scatter plot of the normalised distance from each lobe to its nearest upslope ridge versus its width to length ratio (the closer the value is to 0 , the closer the lobe is to the crest). (b) Scatter plot of slope versus lobe W:L, medians for each population are plotted for each bin of 0.5. (c) Scatter plot of slope versus lobe length. Red markers indicate martian SSL which are shown on their own on the top row, blue markers represent solifluction lobes, which are superposed on SSL on the second row and green markers represent the zebra stripe lobes of the Atacama Desert and are superposed on SSL and solifluction lobes on the third row.

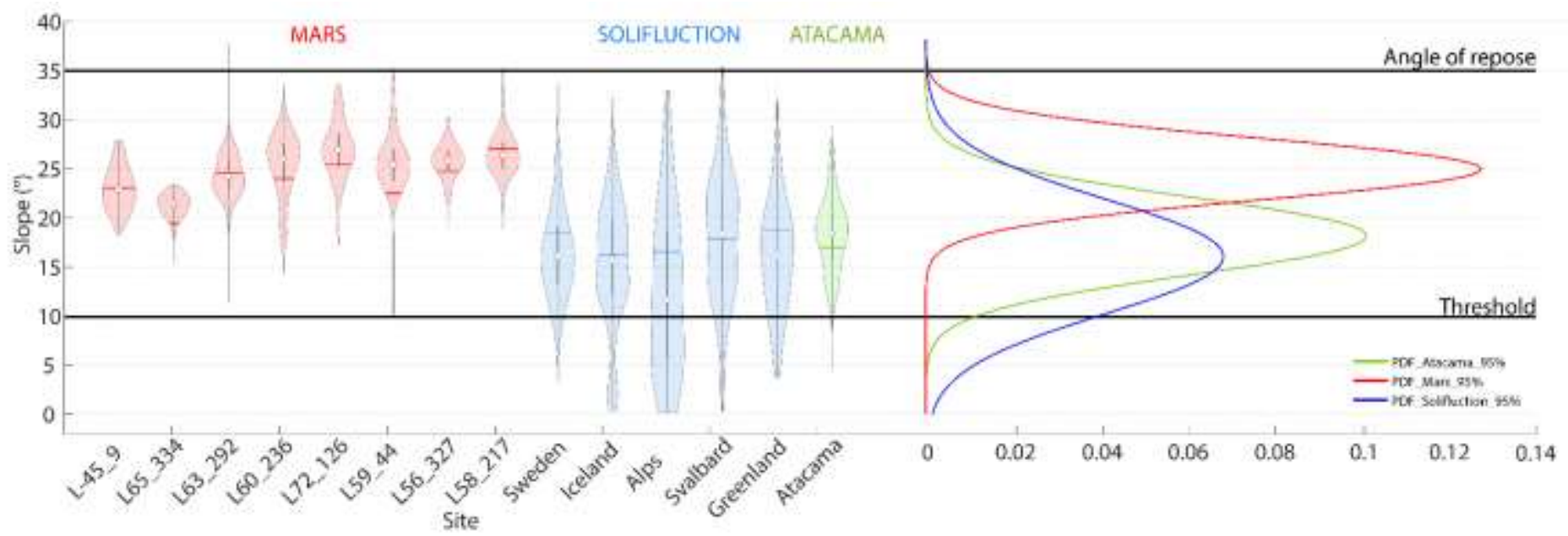

Fig. 10: Violin plot of the distribution of slope for the lobes in each site. White dots and horizontal lines represent mean and median values, respectively. The "violin" represents the shape of the distribution. This plot shows that SSL do not occur below $10^{\circ}$, and that all but 3 of the lobate features studied here occur below the angle of repose of dry loose materials. On the right is plotted the Probability Density Function (PDF) of slopes for lobes on Mars and Earth showing this distribution with a $95 \%$ confidence intervals. 

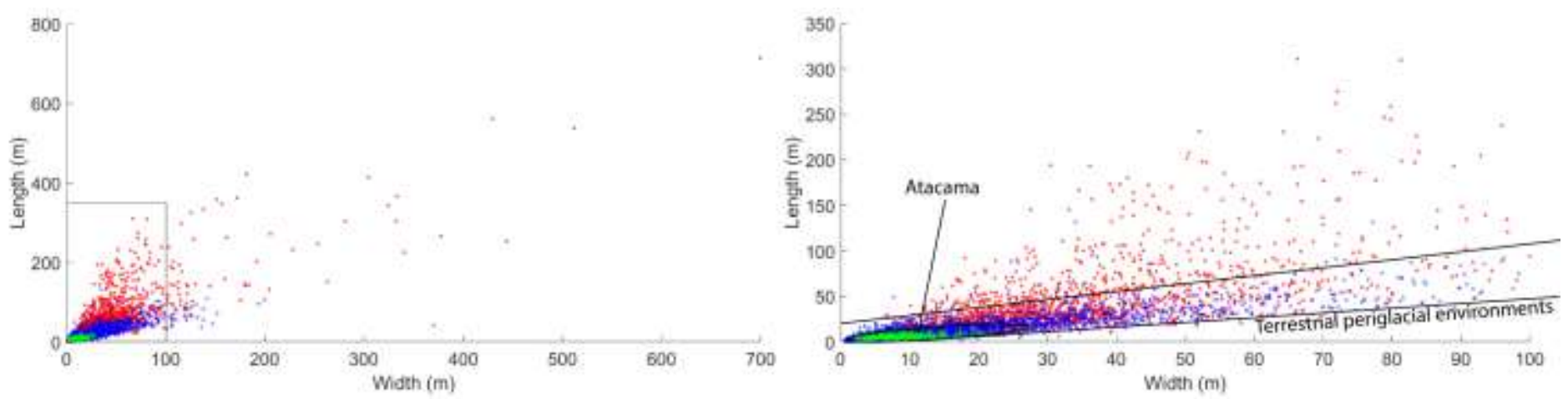

Fig. 11: Scatter plot of lobe length versus lobe width, where the box indicates the location of the detailed plot shown on the right. Red points are martian SSL, blue points are solifluction lobes and green points are zebra stripe lobes in the Atacama. Terrestrial solifluction lobes are generally restricted to the parameter space indicated by the black lines on the right plot.
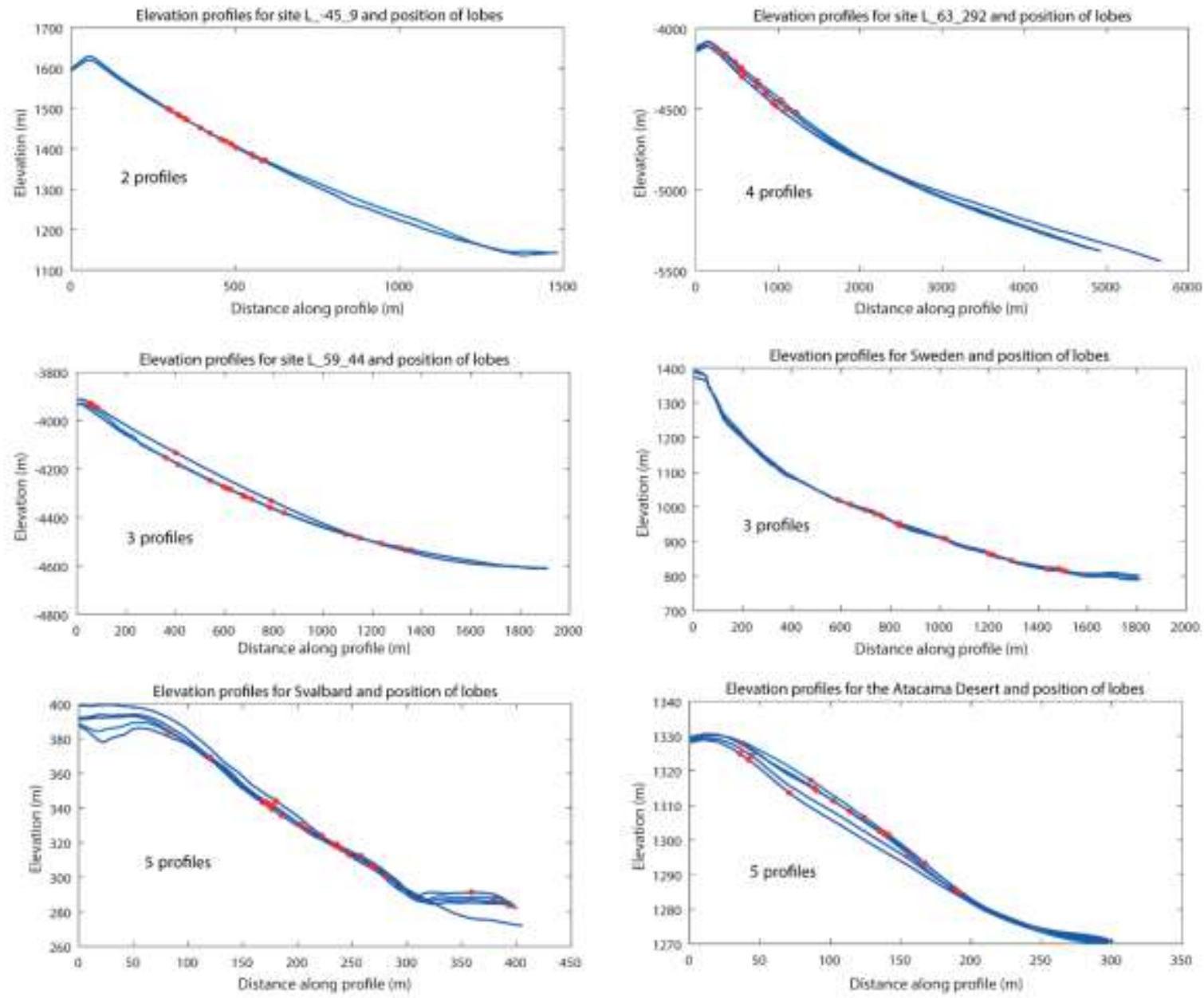

Fig. 12: Example topographic profiles in blue illustrating the typical position of lobate forms in the profile for Earth and Mars. Red dots are individual lobes. Note the different vertical and horizontal scales. 


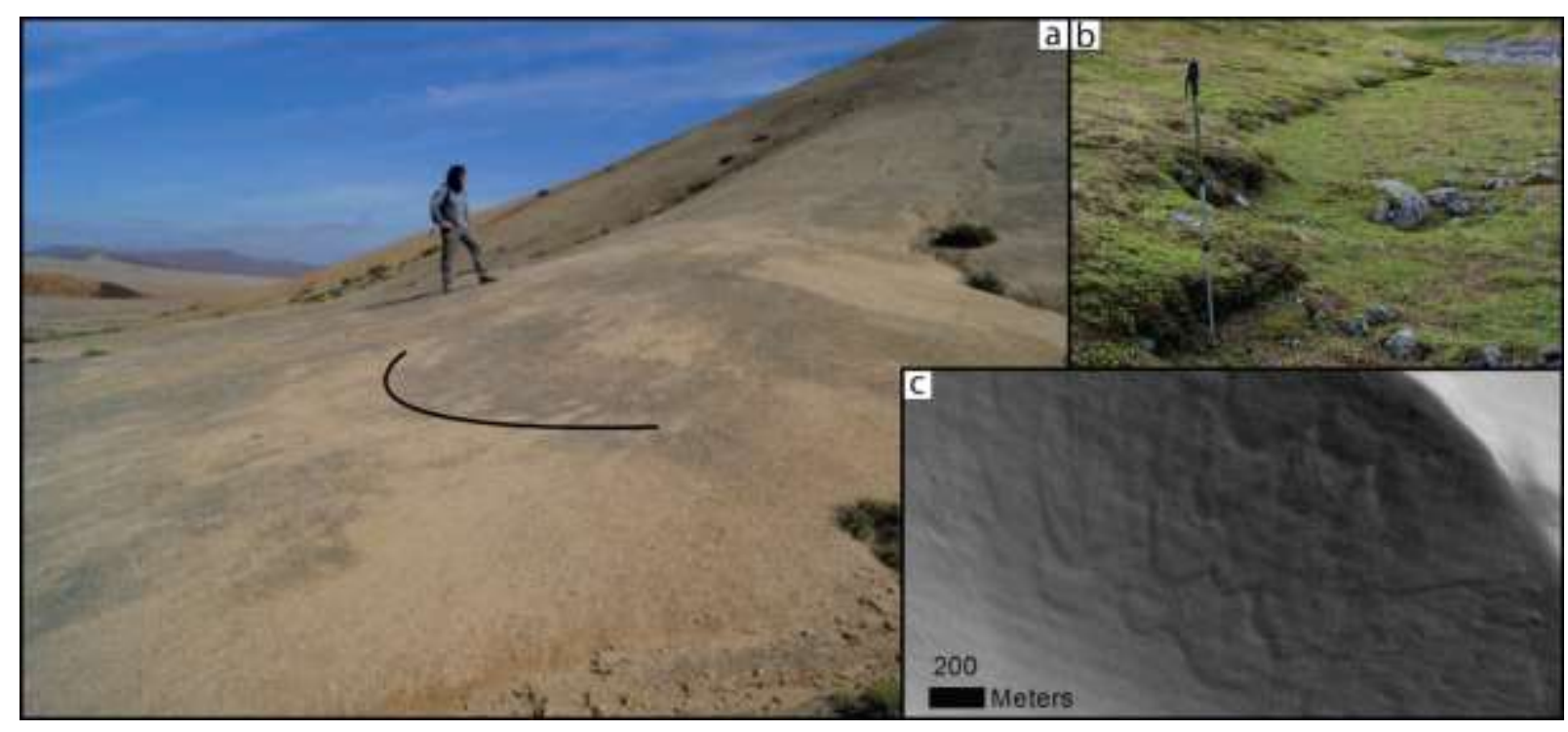

Fig. 13: (a) Photo of zebra stripe lobes in the field, in the Atacama Desert - they are low relief landforms. The black line denotes the shape and the contrast between darkly-varnished gravels and the light-coloured, salt-rich soil. Credit: T. Izquierdo. (b) Photo of solifluction lobes from Abisko, Sweden. Credit: A. Johnsson. The height of the riser is about $30 \mathrm{~cm}$. (c) Hillshaded relief representation of L_65_334 showing that these martian SSL have marked relief (risers approx. $4 \mathrm{~m}$ in height). 


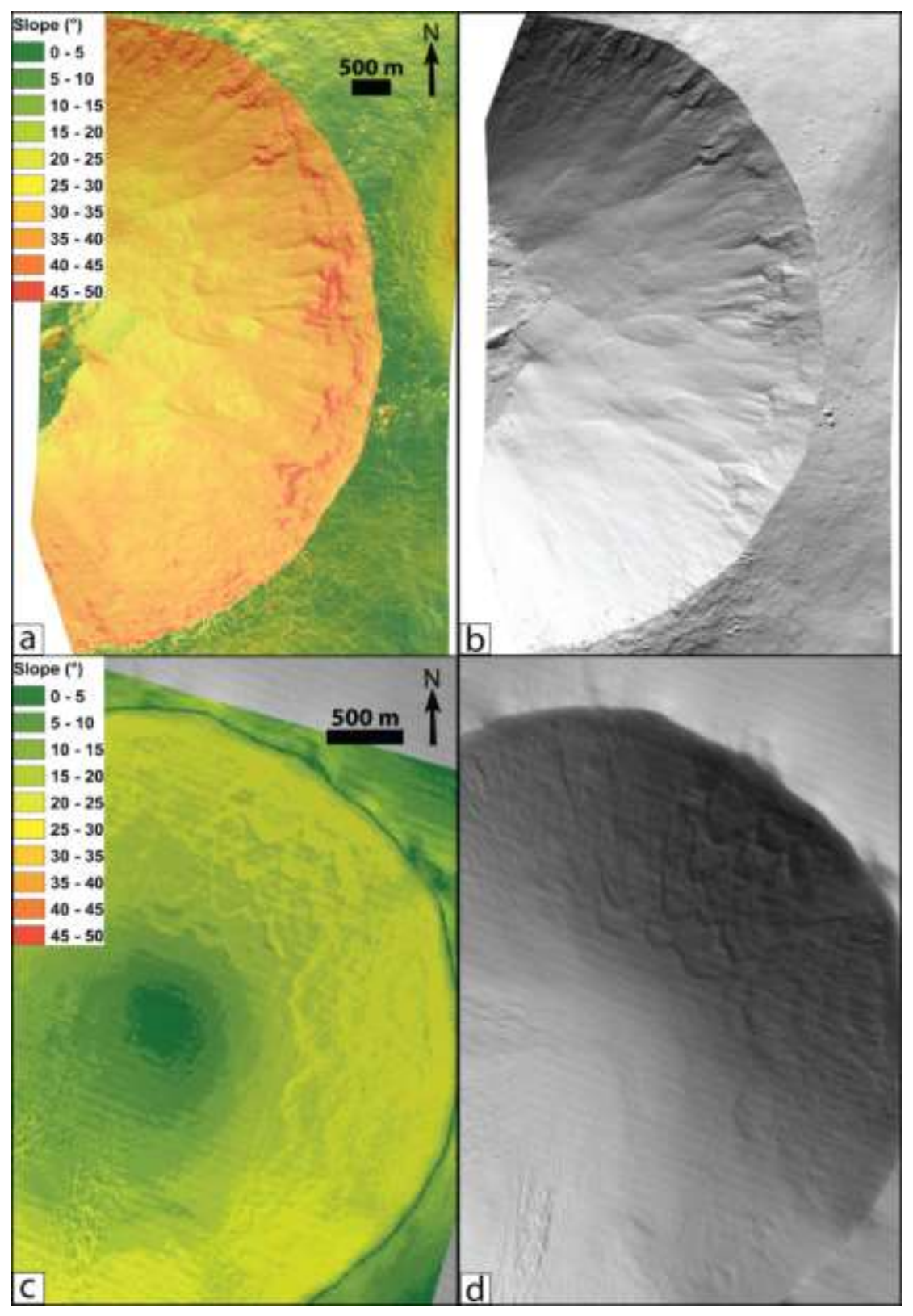

Fig. 14: Lobate forms on Mars and on the Moon. Top: slope (a) and hillshaded relief (b) maps of a crater on the Moon (NAC_DTM_NEARLENTS1_M151169370_70CM), where lobate features are visible. Bottom: slope (c) and hillshade relief (d) maps of a martian crater (site L_65_334) with SSL. 